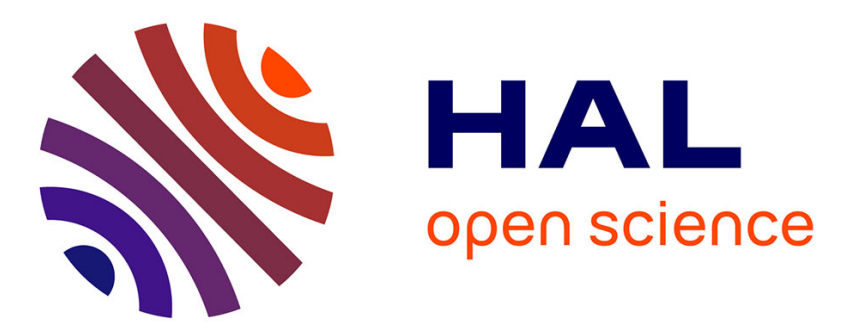

\title{
The Pioneer of Royal Theocracy: Guillaume de Nogaret and the Conflicts between Philip the Fair and the Papacy
}

Julien Théry-Astruc

\section{- To cite this version: \\ Julien Théry-Astruc. The Pioneer of Royal Theocracy: Guillaume de Nogaret and the Conflicts between Philip the Fair and the Papacy. William Chester Jordan; Jenna Rebecca Philipps. The Capetian Century, 1214 to 1314, 22, Brepols, pp.219-259, 2017, Cultural Encounters in Late Antiquity and the Middle Ages, 978-2-503-56718-1. 10.1484/M.CELAMA-EB.5.112974 • hal-02077888}

\section{HAL Id: hal-02077888 \\ https://hal.science/hal-02077888}

Submitted on 8 Jul 2021

HAL is a multi-disciplinary open access archive for the deposit and dissemination of scientific research documents, whether they are published or not. The documents may come from teaching and research institutions in France or abroad, or from public or private research centers.
L'archive ouverte pluridisciplinaire HAL, est destinée au dépôt et à la diffusion de documents scientifiques de niveau recherche, publiés ou non, émanant des établissements d'enseignement et de recherche français ou étrangers, des laboratoires publics ou privés. 


\section{The Capetian Century, \\ 1214-1314}




\title{
CULTURAL ENCOUNTERS IN LATE ANTIQUITY AND THE MIDDLE AGES
}

\author{
General Editor
}

Yitzhak Hen, Ben-Gurion University of the Negev

\author{
Editorial Board \\ Angelo di Berardino, Augustinianum, Rome \\ Nora Berend, University of Cambridge \\ Leslie Brubaker, University of Birmingham \\ Christoph Cluse, Universität Trier \\ Rob Meens, Universiteit Utrecht \\ James Montgomery, University of Cambridge \\ Alan V. Murray, University of Leeds \\ Thomas F. X. Noble, University of Notre Dame \\ Miri Rubin, Queen Mary, University of London
}

Previously published volumes in this series are listed at the back of the book. 


\section{The Capetian Century, 1214-1314}

Edited by

William Chester Jordan and Jenna Rebecca Phillips

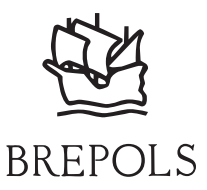


British Library Cataloguing in Publication Data

A catalogue record for this book is available from the British Library

(C) 2017, Brepols Publishers n.v., Turnhout, Belgium

All rights reserved. No part of this publication may be reproduced, stored in a retrieval system, or transmitted, in any form or by any means, electronic, mechanical, photocopying, recording, or otherwise, without the prior permission of the publisher.

$\mathrm{D} / 2017 / 0095 / 29$

ISBN: 978-2-503-56718-1

e-ISBN: 978-2-503-56719-8

DOI: 10.1484/M.CELAMA-EB.5.109362

Printed on acid-free paper 


\section{CONTENTS}

List of Illustrations

vii

Introduction

WILLIAM CHESTER JORDAN

ix

\section{Part I. Royal Patronage and Expressions of Kingship}

The Capetian Monarchy and the University of Paris, 1200-1314 WILLIAM J. COURTENAY

Saint Louis and Cîteaux Revisited: Cistercian Commemoration and Devotion during the Capetian Century, 1214-1314

ANNE E. LESTER

King/Confessor/Inquisitor: A Capetian-Dominican Convergence

SEAN L. FIELD

Kingship and Crusade in the First Four Moralized Bibles

M. C. GAPOSCHKIN

\section{Part II. Power and its Representation}

French Nobility and the Military Requirements

of the King (c. 1260-c. 1314)

XAVIER HÉLARY 
The Managerial Revolution of the Thirteenth Century

The Ambiguity of Representation: Semiotic Roots

of Political Consent in Capetian France

BRIGITTE MIRIAM BEDOS-REZAK

\section{Part III. Philip the Fair and his Ministers}

Philip the Fair and his Ministers:

Guillaume de Nogaret and Enguerran de Marigny

ELIZABETH A. R. BROWN

The Pioneer of Royal Theocracy: Guillaume de Nogaret and the Conflicts between Philip the Fair and the Papacy

JULIEN THÉRY-ASTRUC

Robert Fawtier's Philip the Fair

ÉLISABETH LALOU

\section{Part IV. Crusaders and Crusading Orders}

Travels, Troubles, and Trials: The Montaigu Family

between Capetian France and Lusignan Cyprus

JOCHEN BURGTORF

An Upstart without Prospects? The Familial Context of Renaud of Châtillon and its Implications

PAUL F. CRAWFORD

What Became of the Templars after the Trial of 1307-14?

HELEN J. NICHOLSON

Index 


\title{
THE PIONEER OF ROYAL THEOCRACY: GUILLAUME DE NOGARET AND THE CONFLICTS BETWEEN PHILIP THE FAIR AND THE PAPACY
}

\begin{abstract}
Julien Théry-Astruc*
Il est sans doute de certaines fonctions où, tenant pour ainsi dire la place de Dieu, nous semblons être participans de sa connaissance aussi bien que de son autorité.
\end{abstract}

Louis XIV, Instructions pour le Dauphin (1668)

67 ex Francie venit ad annunciandum vobis gaudium magnum' ('The King of France has come to announce to you a great joy'), Guillaume de Plaisians declared to Pope Clement $\mathrm{V}$ at a consistory in Poitiers on 29 May 1308, in the presence of King Philip IV, the Fair, of France. According to Plaisians, Philip the Fair's adviser, ${ }^{1}$ this 'great joy' (Luke 2. 10), which 'all creatures felt', was the result of the recent victory in what had been the greatest battle ever fought for the faith, for the church, and for the redemption of humanity since the death of Christ on the Cross - that is, the battle waged by Philip the

${ }^{*}$ I am most grateful to Chad Córdova and Elizabeth A. R. Brown for translating this article. My thanks also go to Sean Field, M. Cecilia Gaposchkin, Sara McDougall, Agostino Paravicini Bagliani, and especially to Jenna Phillips. A first version of this article was published as 'Le pionnier de la théocratie pontificale: Guillaume de Nogaret et les conflits de Philippe le Bel avec la papauté,' in Guillaume de Nogaret, un Languedocien au service de la monarchie capétienne, ed. by Bernard Moreau (Nîmes: Lucie Éditions, 2012), pp. 101-28. I would like to thank Lucie Éditions for their kind permission to publish this revised and much augmented English version.

${ }^{1}$ See Henry, 'Guillaume de Plaisians'; Verdier, 'Guillaume de Plaisians, une succession médiévale’; Verdier, 'Guillaume de Plaisians, itinéraire d'un légiste’.

Julien Théry-Astruc (j.theryastruc@gmail.com) Université Lyon II, Louis Lumière

The Capetian Century, 1214-1314, ed. by William Chester Jordan and Jenna Rebecca Phillips CELAMA 22 (Turnhout: Brepols, 2017), pp. 219-259 10.1484/M.CELAMA-EB.5.112974 BREPOLS PUBLISHERS 
Fair against the heresy of the 'perfidious Templars.' ' 'God's Providence', Plaisians insisted, had 'elected' the King of France as his 'minister' to win this battle in his name in order to save humanity. ${ }^{3}$ In using the phrase 'ad annunciandum vobis gaudium magnum', Plaisians equated Philip the Fair with the angel of God who, in the words of the Gospel of Luke, had announced to the shepherds that Jesus Christ was born. ${ }^{4}$ Better still: he also implicitly suggested to Clement V that through the miraculous victory over the Templars, Christ had designated the Capetian king as his new representative on earth - thus virtually challenging the Pope's exclusive right, as 'vicar of Christ', to fulfill this function. ${ }^{5}$ The Roman ordo XIV, which described the rituals for papal election at the end of the thirteenth century, specified that the oldest of the cardinal deacons could (si placet) announce the election to the populus with the formula 'Ecce annun-

${ }^{2}$ Finke, Papsttum und Untergang, II, 141: 'Dixit qualiter dominus noster Jhesus Christus magnam victoriam obtinuerat temporibus istis de inimicis suis, qualis non fuerat a tempore Passionis sue citra. Et post aliqua circa hec dicta subjunxit sic: "Pater sanctissime! Rex Francie non venit pro negotio isto ad vos sicut accusator nec sicut delator nec sicut denunciator nec sicut instructor nec sicut partem faciens, sed venit ad annunciandum vobis gaudium magnum quod est omni creature de victoria ista"'. See also a draft version of the speech edited by Finke at p. 135, and in Le dossier de l'affaire des Templiers, ed. by Lizerand, at pp. 110-12: 'Post illam universalem victoriam quam ipse dominus Jhesus Christi fecit in ligno Crucis contra ostem antiquum pro defensione Ecclesie sue et umani generis redempcione, [...] non fecit aliquam particularem victoriam contra inimicos sue ecclesie et fidei orthodoxe ita miram et magnam et strenuam, ita utilem et necessariam, sicut fecit novissime hiis diebus per ministros delegatos ad hoc in perfidorum templariorum negocio, miraculose detegendo eorum pravitatem hereticam in animorum ipsorum periculum et subversionem fidei et destructionem Ecclesie diutius occultatam?

${ }^{3}$ Finke, Papsttum und Untergang, II, 142: 'Et postquam de hiis locutus est, idem dominus Guillelmus seriose prosecutus est qualiter victoria illa de qua predixit fuit jocunda et mirabilis in progressu propter tria, videlicet propter Dei providentiam eligentem ministrum, propter Dei clementiam providentem magistrum et propter Dei sapientiam ordinantem processum. Dei providentia elegit ad hoc negocium ministrum scilicet regem Francie, qui in regno suo est Dei vicarius in temporalibus, et certo nullus ad hoc magis idoneus inveniri potuisset'. See also Le dossier de l'affaire des Templiers, ed. by Lizerand, p. 126: 'Rex Francorum [...] ut minister Dei, pugil fidei catholice, legis divine zelator, ad deffensionem Ecclesie, juxta traditiones patrum sanctorum, de qua tenetur Deo reddere rationem',

${ }^{4}$ Luke 2. 10: 'Ecce evangelizo vobis gaudium magnum quod erit omni populo, quia natus est vobis hodie salvator, qui est Christus Dominus, in civitate David'.

5 See Maccarone, Vicarius Christi; Paravicini Bagliani, The Pope's Body, pp. 58-59, 80, 86-87; Paravicini Bagliani, Le chiavi e la tiara, pp. 43-59; Paravicini Bagliani, Il papato nel secolo XIII, p. 175; Paravicini Bagliani, Morte ed elezione, pp. 116-17; Théry-Astruc, 'Introduction'. 
cio vobis gaudium magnum. ${ }^{6}$ As Agostino Paravicini Bagliani has emphasized, this suggested that the newly elected pope took over the function, on earth, of Christ himself. The passage from Luke is echoed in Paul's declaration (Acts 17.3), 'Hic est Christus Jesus quem ego annuncio vobis.' Philip the Fair and his advisers certainly knew about the ritual use and meaning of this passage. Later in his speech to Clement, Plaisians explicitly asserted that the King of France was 'God's vicar in his kingdom for temporal matters.'

The claim to a religious, Christic leadership had lain at the heart of royal policy towards the papacy since the outbreak of the great conflict between Boniface VIII and Philip the Fair in 1301. The chief architect of this campaign was Plaisians's master, Guillaume de Nogaret. At Poitiers Plaisians spoke in Nogaret's place, since Nogaret was not permitted to appear before Clement V, having been placed under a sentence of excommunication after the attack on Boniface VIII at Anagni in 1303. But the words Plaisians spoke were surely those of Nogaret.

Nogaret is the most famous of the legists who advised Philip the Fair ${ }^{9}-$ those jurists whom Michelet called the 'cruel demolishers of the Middle Ages' because they single-mindedly sought to insure the triumph of the French royal state over all rival powers, and especially over the church and the great secular

${ }^{6}$ Dykmans, Le cérémonial, II, 268-9, no. 11 (cited by Paravicini Bagliani, Morte ed elezione, p. 115 and n. 227): 'Cum autem predicte Romane ecclesie fuerit de pastore provisum, prior diaconorum dictam electionem populo annuntiat dicens si placet: "Ecce annuntio vobis gaudium magnum", vel aliud thema sicut placebit. For the date of ordo XIV, see Schimmelpfennig, Die Zeremonialbücher, pp. 62-100.

${ }^{7}$ Paravicini Bagliani, The Pope's Body, pp. 66 and 277; Paravicini Bagliani, Morte ed elezione, pp. 115-17. The first French chronicler to mention the formula Ecce annuncio is Amalric Augier (c. 1320), Actus Romanorum pontificum in Rerum Italicarum Scriptores, III.2, c. 9 (indicated by Paravicini Bagliani, Morte ed elezione, p. 115 and n. 228): 'Item quod cum deinde ipse Dei Filius ex Maria Virgine gloriosa natus fuisset, statim in die Nativitatis suam promotionem et coronationem a Deo Patre sibi factas, universo mundo et maxime in partibus orientalibus per suos sanctos angelos denuntiare fecit et publicari, juxta testimonium dicti evangeliste Luce, qui sic ait: "Annuntio vobis gaudium magnum et cetera". [...] Cujus auctoritate pariter et exemplo in cujuslibet Romani pontificis assumtione prior diaconorum cardinalium promotionem cujuslibet Romani pontificis et ejusdem nomen populo ex officio suo denuntiare debet'.

${ }^{8}$ Finke, Papsttum und Untergang, II, 142 (see above, at note 3).

${ }^{9}$ Renan, 'Guillaume de Nogaret, légiste'; Holtzmann, Wilhelm von Nogaret; Melville, 'Guillaume de Nogaret et Philippe le Bel'; Nadiras, 'Guillaume de Nogaret et la pratique du pouvoir'; Nadiras, 'Guillaume de Nogaret'; Moreau, Guillaume de Nogaret; Moreau and ThéryAstruc, La royauté capétienne et le Midi; Pegues, The Lawyers of the Last Capetians. See also Elizabeth A. R. Brown's contribution in the present volume. 
lords. ${ }^{10}$ Enguerran de Marigny, who, with Nogaret, was a leading strategist and royal adviser during the second half of Philip's reign, oversaw royal financial operations and orchestrated the King's dealings with secular lords. ${ }^{11}$ Nogaret's domain comprised relations with the church and the papacy. ${ }^{12}$ His notoriety stems chiefly from two notorius events: the indictment of Pope Boniface VIII for heresy $(1303)^{13}$ and the attack on the Templars (1307-14). ${ }^{14}$ Some years earlier, however, he had already played a dominant role in another ecclesiastical affair: the arrest and prosecution in 1301 of Bernard Saisset, Bishop of Pamiers. This incident is less well known, but its consequences were momentous. ${ }^{15}$ In examining the prosecution of Saisset, I hope to show the importance of Nogaret's intervention and the decisive effect of this campaign on subsequent royal policy. Nogaret's initiatives were, I will argue, extraordinarily bold, and they would prove critically important for the future. At a time when the growth of the state was challenging papal claims to universal jurisdiction, these initiatives not only affirmed the superiority of the French king, but also infused the power he exercised with religious and absolutist elements that made the French monarchy a virtual theocracy.

By 1295 or 1296, when Nogaret joined the central royal administration and began to serve Philip the Fair directly, the Capetian dynasty had long since acquired a singular aura of sacredness. Robert the Pious (996-1031), son and successor of the dynasty's founder, Hugues Capet, had gained the reputation of being an occasional miracle worker. Beginning with Louis VI (1106-37), the French kings were believed to heal scrofula by touching the afflicted, who flocked to them from throughout the West in hopes of being cured. Consecration at Reims was thought to provide French kings with this supernatural ability. This ceremony produced a dynasty that was quasi-sacerdotal. ${ }^{16}$

${ }^{10}$ Michelet, Histoire de France, III (1840), 272.

${ }^{11}$ Favier, Un conseiller de Philippe le Bel; and see Elizabeth A. R. Brown's comparison between Nogaret and Marigny in her contribution to the present volume.

12 Digard, Philippe le Bel.

13 Schmidt, Der Bonifaz-Prozess; Boniface VIII en procès, ed. by Coste.

${ }^{14}$ Barber, The Trial of the Templars; Théry-Astruc, 'Procès du Temple'; Théry, 'A Heresy of State'; Burgtorf, Crawford, and Nicholson, the Debate on the Trial of the Templars; Demurger, La persécution des templiers.

15 Vidal, 'Bernard Saisset'; Digard, Philippele Bel, II, 51-62 and 70-81; McNamara, Gilles Aycelin, pp. 98-112; Denton, 'Bernard Saisset'; Théry, 'Allo scoppio del conflitto'. See also Strayer, The Reign of Philip the Fair, pp. 260-67; Lewis, Royal Succession, pp. 138-39.

${ }^{16}$ Bloch, The Royal Touch. 
Above all, it gave rise to a particular affinity between the Capetian king and God, for it recalled the baptism of Clovis by St Remy, which had made the Franks the first of the Germanic people to accept the Catholic Church. The holy chrism used by Remy's successors, the archbishops of Reims, was taken from a vessel known as the Holy Ampulla, believed to have been brought by the Holy Spirit, in the form of a dove, for Clovis's anointing, and treasured at Reims as the church's holiest relic. ${ }^{17}$ Other monarchies, especially the English, attempted to acquire similar sacredness. ${ }^{18}$ None, however, had the success of the Capetians, who in the twelfth century begun to present themselves as the special defenders, supporters, and partners of the apostolic see. The theocratic papacy was then in process of expanding and consolidating its own prerogatives. The church was transformed into a papal monarchy, and the popes demanded plenitudo potestatis, 'plenitude of power', a power that was superior to that held by all princes, because it was dedicated to universal salvation. This led to prolonged conflict with the emperors, dubbed by French historians the 'Querelle du Sacerdoce et de l'Empire', during which the popes regularly took refuge in France. As early as 1107, Pascal II's visit to Saint-Denis inaugurated an alliance between the Capetian kings and Rome. ${ }^{19} \mathrm{~A}$ half century later, in return for the warm welcome that Louis VII offered to Pope Alexander III, the Capetian King was accorded in 1161 the title rex christianissimus, and two years later Alexander presented him with a special gift, a golden rose, 'the symbol of Christ-King' - distinctions which other princes occasionaly enjoyed too, it should be noted. ${ }^{20}$ Louis VII was the first king to take the Cross and participate in a Crusade, a move that challenged other rulers to imitate his act. The support Louis VII gave to Thomas Becket, Archbishop of Canterbury, during his struggle with Henry II of England also redounded to the French King's reputation after Thomas was martyred and canonized.

17 Beaune, Birth of an Ideology; Isaïa, 'Objet du sacre, objet sacré?’; Isaïa, Remi de Reims.

18 Vincent, The Holy Blood.

${ }^{19}$ See, for instance, Barthélemy, Nouvelle histoire des Capétiens, pp. 150-51.

${ }^{20}$ Patrologia Latina, ed. by Migne, cc, col. 100 (see also Patrologia Latina, ed. by Migne, CC, cols 158, 165, 181, 268; King Henry II of England, for instance, was also called rex christianissimus by Alexander III: Patrologia Latina, ed. by Migne, cc, cols 375, 426, 467, etc; so was King William of Sicily: Patrologia Latina, ed. by Migne, Cc, col. 1000); Patrologia Latina, ed. by Migne, CC, cols 198-99, and Recueil des historiens, ed. by Bouquet and others, XV, 794 ('Flos iste Christum regem exprimit ac designat'). On the golden rose, which Eugene III had sent to King Alfons of Castilla in 1148 (Patrologia Latina, ed. by Migne, CLXxx, col. 1346), see Paravicini Bagliani, The Pope's Body, pp. 82-83. 
During the thirteenth century, Louis VII's successors cultivated the close relationship with the Roman Church and worked with the popes in such solidarity that they appeared to be its special military defenders. Louis VIII took up the Cross against the 'Albigensian heretics' and, fighting for the faith, prepared the way for the French Crown's annexation of the county of Toulouse. Although he had simply fallen ill and died, his death on his return to northern France in 1226 was later interpreted as a crusader's martyrdom. Louis IX gave a particular Christic dimension to the monarchy when he acquired the relics of the Passion, and most notably the Crown of Thorns, and by transferring them ceremoniously from Constantinople to Paris. There they were finally installed at the very centre of Capetian power, in the jewel-like Sainte-Chapelle that Louis had built to house them, in the royal palace on the Île de la Cité. ${ }^{21}$ Louis also made himself the champion of the papal theocracy's largest venture, the Crusade against the infidels. Despite the disastrous outcomes of his two expeditions to reconquer the Holy Land (1248-54 and 1270), those campaigns, together with his celebrated piety and wisdom, earned him a saintly reputation during his lifetime and added lustre to the religious aura already surrounding his line. ${ }^{22}$ Very shortly after Louis died near Tunis, his son, Philip III, wrote a letter to the people of France comparing his death to Christ's. Louis, Philip wrote, had lain with his arms extended as if he were on a cross, and he had died 'hora illa qua dominus Jhesu Christus Dei filius in cruce pro mundi vita moriens expiravit' ('at the very hour when Lord Jesus Christ, Son of God, dying for the life of the world, expired on the Cross'). ${ }^{23}$ In the letter Philip represented himself as Louis's 'lieutenant on earth', which implicitly equated Louis with Jesus Christ, since the popes used the phrase locum tenens in terris to describe their function of the representatives of Christ on earth. ${ }^{24}$ Louis's confessor, Geoffroy de Beaulieu, drew no such bold analogies, but he described the King's death as 'a perfect sacrifice' (holocaustum integrum) and called Louis 'Christ's host'. ${ }^{25}$

${ }^{21}$ Le Goff, Saint Louis, pp. 94-101; Mercuri, Corona di Cristo; Gaposchkin, The Making of Saint Louis; Gaposchkin, 'Louis IX and Liturgical Memory'; Charansonnet, Morenzoni, 'Prêcher sur les reliques de la Passion'.

22 See in particular Gaposchkin, 'The Place of the Crusades'; Hélary, La dernière croisade.

${ }^{23}$ Cartulaire, ed. by Guérard, I, 189-22, at p, 190. See Gaposchkin, The Making of Saint Louis, pp. 25-30.

${ }^{24}$ Cartulaire, ed. by Guérard, I, 191: 'O quis nobis daret, tenentibus locum ejus in terris, talis ac tam laudabilis progenitoris sequi vestigia et imitari exempla'.

25 See Le Goff, Saint Louis, p. 723. 
A few years before Louis's edifying and Christ-like death, his brother Charles of Anjou had gone to the aid of the papacy in Italy. Through his military victories in 1266 and 1268, Charles had rid the popes of the last of the Hohenstaufens, the imperial dynasty that, since the 1230s, had again attacked the Roman Church. Clement IV, as a reward for this intervention, which he deemed a crusade, awarded Charles the Kingdom of Sicily. Thus, a collateral branch of the Capetian dynasty found itself at the head of an Italian monarchy subordinated to the apostolic see. When, in 1282, following the Sicilian revolt against the Angevins, King Peter III of Aragon conquered Sicily, the church called for a crusade against him. It was only natural that Louis's son Philip, nephew of the King of Sicily, should assume leadership of the campaign, when his youngest son, Charles de Valois, was awarded the crown of Aragon to punish Peter III. Philip III's death on his return from the so-called crusade against Aragon in 1285 again fortified the image of the French rulers as zealous servants of the Catholic faith. Philip, just like Louis VIII, Louis IX, and Robert d'Artois (Louis IX's younger brother, who died fighting in Egypt, at the Battle of Mansurah, in 1250), could be said to be a martyr of the Crusade.

In 1285, at the accession of Philip III's son and namesake Philip the Fair, the royal attitude towards the papacy was profoundly transformed. To be sure, French solidarity with the papacy was, for the moment, assumed. Just as before - and even more - the King publicized and profited from the honours the papacy had bestowed on the Capetian house because of its services to the Roman Church. Indeed, the King and his advisers sought even greater honours, succeeding in 1297 in obtaining the canonization of Louis IX, which, in their view, dramatically demonstrated the superiority and supremacy of the Capetians. ${ }^{26}$ A radical change occurred, however, in the relationship between the King and the ecclesiastical powers within the kingdom. Before 1285 ecclesiastical and royal jurisdictions had operated in relative harmony. Tensions naturally existed, because of conflicting claims to administer justice and collect revenue. ${ }^{27}$ But the situation set in place at the end of the eleventh and beginning of the twelfth century by the Gregorian Reform, which put ecclesiastical possessions out of reach of secular intrusion, remained fully operative. Around 1285, however, the

26 Carolus-Barré, Le procès de canonisation; Gaposchkin, 'Boniface VIII, Philip the Fair'; Gaposchkin, 'Louis IX and Liturgical Memory'.

${ }^{27}$ Berger, Saint Louis et Innocent IV; Congar, 'L'Église et l'État'; Campbell, 'The Protest of Saint Louis'; Campbell, 'The Attitude of the Monarchy'; Campbell, 'Clerical Immunities in France'; Campbell, 'Temporal and Spiritual Regalia'; Le Goff, Saint Louis, at pp. 118-21 and $781-85$. 
royal administration began systematically attacking and restricting rights and powers claimed by the church. Indeed, the saintly Louis IX had firmly defended royal rights against encroachment by the church, but he also controlled overzealous royal officials. Under Philip the Fair, in contrast, the King's agents began to move against episcopal and monastic property and jurisdiction throughout the whole kingdom. The pace of their attacks seems to have quickened from year to year. Tensions increased particularly after 1294, with the election of Pope Boniface VIII, a stubborn man, committed to theocratic principles. ${ }^{28}$ Still, before the Saisset affair and Nogaret's intervention, the situation in France was similar to that in other countries, like England, where monarchical power was growing. ${ }^{29}$ The bull Clericis laicos, for example, which reiterated the traditional ban on taxing the clergy without papal consent and imposed heavy penalties for infringing it, was aimed at Edward I as much as at Philip the Fair.

The conflict between the Pope and the King of France escalated dramatically when Philip's advisors, Nogaret foremost among them, shifted the dispute from practical cases to questions of principle. As we shall see, Nogaret took it upon himself to use both the Capetian dynasty's accumulated spiritual capital and its traditional ties to the Roman Church in an attempt to bring about a major reversal: namely, to claim on behalf of the King the politicoreligious attributes of papal theocracy. If Nogaret did not compose it himself, he certainly had a hand in writing the short polemical tract known from its first words as Antequam essent clerici, 'Before There Were Clerics. ${ }^{30}$ This text challenged the legitimacy of privileges the clergy had claimed since the time of Pope Gregory VII. Questioning particularly clerical claims to fiscal immunity, the tract asserted that the institution of kingship preceded that of the church and its clergy and derived its universal and superior authority from the protection it afforded to the faith and the faithful. Antequam essent clerici is one of a long series of tracts devoted to the respective prerogatives of the Pope and of the King of France that appeared during the conflict between Boniface VIII and Philip the Fair. ${ }^{31}$ The text dates to 1296, the first year that Nogaret was active in

${ }^{28}$ Dupré-Theseider, 'Bonifacio VIII'; Paravicini Bagliani, Boniface VIII.

29 Denton, Robert Winchelsey.

${ }^{30}$ Dupuy, Histoire du différend, pp. 21 -23, also in Recueil général, ed. by Jourdan, Decrusy, and Isambert, II, 706-09, and, with an English translation, Three Royalist Tracts, ed. by Dyson, pp. 2-11. The only extant copy of the tract is found in the register Paris, BnF, f. lat. 10919, which, as E. A. R. Brown has recently shown, was most probably made under Nogaret's supervision and for his personal use (see Brown, 'Guillaume de Nogaret et les textes').

${ }^{31}$ See 'A Dispute Between a Priest and a Knight', ed. and trans. by Erickson; Three Royalist 
the royal court. It contains a quotation from St Augustine, 'turpis enim est pars que suo non congruit universo' ('for any part that is not in harmony with the whole is corrupt'), which is also found in the draft of another treatise, this one dealing with the French annexation of Lyon, which was unquestionably written by Nogaret. ${ }^{32}$ Using these words in the Confessions (III, 8), Augustine was concerned with the individual Christian and the church. In Antequam essent clerici, the phrase was applied to the relationship between the kingdom's inhabitants, both clerical and lay, and the kingdom itself as a collective entity, the cohesion of which was secured by royal authority. Deploying the biblical, patristic, and canonical principles in contexts of royal and national politics became a hallmark of Nogaret's writings. ${ }^{33}$ But Antequam essent clerici might be the work of Pierre Flotte, another 'legist', who exercised considerable power before his death in 1302, who oversaw royal policies towards the church when Nogaret arrived at court, and who probably influenced Nogaret's attitudes, strategies, and modes of argumentation. ${ }^{34}$ Whatever the case, beginning in 1301 Nogaret played a crucial role in an affair that led directly to the outbreak of the great conflict with Boniface VIII: the Saisset affair.

Among the numerous areas throughout France where an increasingly active royal administration had attacked ecclesiastical jurisdiction, two places were particularly critical: the first is Lyon, an imperial city where the archbishop exercised temporal power, and over which the King of France claimed lordship $;{ }^{35}$ the second is Pamiers, ${ }^{36}$ a small town at the foot of the Pyrénées, some $60 \mathrm{~km}$ north of what is now the Spanish border (in the departement of the Ariège). There, as in many places in the southern half of France, the church and a temporal lord were locked in interminable disputes over jurisdictional rights. The conflict pitted the canons of Saint-Antonin of Pamiers against the Count of Foix. In 1269, the canons had chosen to offer Louis IX a share in their powers of lordship over

Tracts, ed. by Dyson; Briguglia, Fiocchi, and Simonetta, Filippo il Bello e Bonifacio VIII; Briguglia, La questione del potere.

${ }^{32}$ Paris, AN, J 263/21 ${ }^{\mathrm{G}}$. This text is edited in Nadiras, 'Guillaume de Nogaret', II, 746.

33 See Théry-Astruc, “'Les Écritures ne peuvent mentir”; Théry-Astruc, 'Les "États généraux" de Lyon'.

${ }^{34}$ Pegues, The Lawyers of the Last Capetians, pp. 87-91.

35 Bonnassieux, De la réunion de Lyon à la France; Nadiras, 'Guillaume de Nogaret', I, 427-552; Théry, '1312: Lyon devient française'; Galland, 'La “réunion” de Lyon'; Charansonnet and others, Lyon, entre Empire, pp. 265-412 (section III, 'De l'évêché d'Empire à l'annexion capétienne (1226-1306)'); Nadiras, 'Le tournant décisif'.

36 See the references given above, at note 15 . 
the town, so as to keep the count at bay. But in 1285, Count Roger-Bernard III obtained from the young Philip the Fair surrender of this share. Bernard Saisset, the Abbot of Saint-Antonin, immediately challenged this decision before the royal court, and lengthy litigation followed. ${ }^{37}$ The King finally ruled in favour of the Count. Philip's decision doubtless aimed to maintain good relations with Roger-Bernard III de Foix (and to dissuade him from allying with the King of England, who was also Duke of Gascony), but it also very clearly challenged the papacy, which had invested this local affair with significant importance by strongly supporting the aggressive and combative Bernard Saisset. In March 1292 Pope Nicholas IV had gone so far as to put Saint-Antonin under the direct protection of the apostolic see - and he had appointed Cardinal Benedetto Caetani, the future Boniface VIII, as its special protector. ${ }^{38}$

With the King's backing, the Count of Foix seized rights of lordship over Pamiers in March 1295. Saisset fled and took refuge at the papal court in Rome. Cardinal Benedetto Caetani had been elected Pope as Boniface VIII on 25 December 1294. On 17 June 1295, he sent a letter of scathing rebuke to Philip the Fair. ${ }^{39}$ On the same day, he also issued a sentence of excommunication against Count Roger-Bernard and put the town of Pamiers under interdict. ${ }^{40}$ Then, between July and December of 1295 , he took a variety of radical steps concerning Pamiers that were meant to demonstrate the independence with which ecclesiastical jurisdiction could and should be exercised within the kingdom of France - free of accountability to the king and without any consultation with him. First - and certainly most important in understanding the royal measures that came next - without consulting or notifying Philip the Fair, Boniface transformed Pamiers into an episcopal see, thus modifying France's ecclesiastical geography to create a new diocese (the territory of which was taken from that of Toulouse). The abbey church of the canons of SaintAntonin thus became a cathedral. ${ }^{41}$ Its property was transformed into the temporalities of a bishop - all without raising the question of the rendition of

37 Vidal, 'Bernard Saisset', pp. 570-90; Digard, Philippe le Bel, I, 225-27.

38 The papal bull is only known from a seventeenth century copy (Paris, BnF, coll. Doat, t. 94, fol. 108); see Vidal, 'Bernard Saisset', p.571.

39 The arenga of the bull is edited in Les registres de Boniface VIII, ed. by Digard and others, no. 162, and the rest of the text in Dupuy, Histoire du différend, p. 625.

40 Summary of the bull in Les registres de Boniface VIII, ed. by Digard and others, no. 161.

${ }^{41}$ Summaries of the bulls (dated 23 July 1295) in Les registres de Boniface VIII, ed. by Digard and others, nos. 411-12; editions in Gallia christiana, XIII, Instrumenta, cols 98-99. 
homage, which French bishops usually owed to the king. Abbot Bernard Saisset, who was known as a champion of ecclesiastical independence and as a personal friend of Boniface VIII, was named first Bishop of Pamiers on 23 July $1295 .{ }^{42}$

A few years later, the new bishop founded a chapel dedicated to St Boniface in the new cathedral - a highly significant step (and probably a consciously provocative one). Unsurprisingly, Pope Boniface granted Saisset official confirmation of what appeared to be an indirect but unmistakable tribute to himself through the eponymous saint (who, incidentally, had been the first prelate to consecrate a Frankish king in 751). In a bull dated 20 February 1298, the Pope 'heard out with magnanimity' the Bishop's 'supplication' and approved the foundation. ${ }^{43}$

At the end of 1295, Boniface also created in Pamiers a tribunal of the Inquisition for the prosecution of heresy, whose judges, by definition, reported solely and directly to the pope. ${ }^{44} \mathrm{He}$ also instituted at Pamiers nothing less than a studium generale, a university. There was absolutely no need and no demand for an institution of this kind in Pamiers, and in fact none ever existed except on the parchment of the bull decreeing its foundation. ${ }^{45}$ But such an act, rare and solemn, was a papal prerogative that was not subject to royal intervention or scrutiny.

Little attention seems to have been paid to Pamiers during the next three or four years, when relations between Philip the Fair and Boniface were strained

42 Summary of the bull in Les registres de Boniface VIII, ed. by Digard and others, no. 412bis; edition in Vidal, Documents, pp. 16-20. In the bull, Boniface mentioned the fact that he had personaly known Saisset and particularly appreciated him during his stay at the papal curia: 'Merita [...] que tua diutina et laudabilis apud Sedem apostolicam conversatio nostris sensibus nota fecit' (cited by Vidal, 'Bernard Saisset', pp. 581, n. 1, and 59). The name of Saisset appears as early as 1286 among the witnesses of a ruling by Cardinal Benedetto Caetani (Les registres d'Honorius IV, ed. by Prou, no. 666; see Digard, Philippe le Bel, I, 227, n. 2). In 1269, Saisset already bore the title of papal chaplain: see Vidal, 'Bernard Saisset', p. 581.

${ }^{43}$ Summary of the bull in Les registres de Boniface VIII, ed. by Digard and others, no. 2465; see Vidal, 'Bernard Saisset', pp. 59-60.

${ }^{44}$ Summary of the bull (dated 21 December 1295) in Les registres de Boniface VIII, ed. by Digard and others, no. 606; edition in Vidal, Documents, pp. 24-25; see Vidal, 'Bernard Saisset', p. 63, and Vidal, Le tribunal d'inquisition de Pamiers. This tribunal was later presided over by Jacques Fournier, the future Benedict XII (1334-42), who brought a copy of the inquisitorial proceedings to Avignon. It was from these records that Emmanuel Le Roy Ladurie wrote Montaillou, the Promised Land of Error.

45 Summary of the bull (dated 18 December 1295) in Les registres de Boniface VIII, ed. by Digard and others, no. 658; edition in Vidal, Documents, pp. 23-24. 
by conflict over royal taxation of ecclesiastical property. ${ }^{46}$ This 'premier différend', as historians have called it, commenced when Boniface issued the bull Clericis laicos (24 February 1296). It was quickly resolved. A phase of détente followed, which Robert-Henri Bautier has seen as a period of 'Franco-pontifical alliance. ${ }^{47}$ The rapprochement between the Pope and the King was marked by the canonization of Louis IX, which Boniface decreed on 11 August 1297 a move for which Philip the Fair and his advisers had been pressing since his accession. ${ }^{48}$

In Pamiers, Bishop Saisset and Count Roger-Bernard reached a compromise over lordship rights at the end of $1297 . .^{49}$ Boniface waited more than a year before confirming the agreement in a bull dated 17 February $1299 .{ }^{50} \mathrm{He}$ still demanded a full and solemn submission from the citizens of Pamiers before lifting the interdict that had been imposed for more than three years. The people of Pamiers seem not to have been particularly eager for reconciliation, and in a letter issued on 28 November 1299, Boniface put them under major excommunication, threatening prosecution for heresy by the local inquisitors if they did not submit within the year. Then, when this time expired, in the first months of 1301, Bishop Saisset proceeded to depose the city's consuls on the Pope's behalf. In April 1301, the citizens of Pamiers appealed to the Archbishop of Narbonne, to the Pope, and to the King of France. ${ }^{51}$

Who initiated the events that occurred shortly thereafter - Philip the Fair himself, Pierre Flotte, Nogaret, or other royal advisers - is unknown. At the end of May 1301, royal 'investigators-reformers' (enquêteurs-réformateurs) sent on a special mission to the south began secretly investigating accusations of high treason (proditio) against Bernard Saisset. On the basis of 'common report' (fama communis), the Bishop was accused of having made insulting remarks about the King's person and, most important, of having incited a popular uprising in Languedoc to install as the region's ruler the Infante of Majorca. The tes-

46 See Digard, Philippe le Bel, I, 246-97; Denton, 'Taxation and the Conflict'; Barbero, 'Bonifacio VIII', pp. 282-84; Paravicini Bagliani, Boniface VIII, pp. 139-55.

${ }^{47}$ Bautier, 'Le jubilé romain'.

48 See Digard, Philippe le Bel, I, 218; Carolus-Barré, Le procès de canonisation; Gaposchkin, The Making of Saint Louis.

${ }^{49}$ Vidal, 'Bernard Saisset', pp. 581-86. The text of the agreement is edited in Gallia christiana, XIII, instrumenta, cols 100-103.

${ }^{50}$ Edition of the bull in Les registres de Boniface VIII, ed. by Digard and others, no. 2907.

${ }^{51}$ Vidal, 'Bernard Saisset', pp. 589-90. 
timony of twenty-three witnesses was secretly heard and recorded. ${ }^{52}$ Saisset was quickly arrested. His servants were tortured..$^{53} \mathrm{He}$ was taken north, to the Îlede-France, to appear before the King. All these actions blatantly and unprecedentedly violated ecclesiastical immunity, and particularly the pope's absolute and exclusive jurisdiction over bishops. To all appearances, the problems Saisset confronted now had no connection with the earlier clash between the monarchy and papacy over jurisdictional rights in Pamiers. But only those events can explain and account for the attack on him.

On 24 October 1301, Saisset appeared before the royal council in Senlis. Two accounts of this occasion exist, both produced by prelates who participated in the council. The first account was written at the end of the day by the Bishops of Béziers and Maguelonne; ${ }^{54}$ the second one was issued by the Archbishop of Narbonne or his entourage a few days later. ${ }^{55}$ The session was heated. After Pierre Flotte read aloud the accusations against Saisset, the indignant barons rose up to attack the Bishop. One of the most prestigious, Robert of Artois, threatened to kill the traitor immediately. These intimidations were designed to place Gilles Aycelin, Archbishop of Narbonne, in an awkward position. ${ }^{56}$ Present at the council, he was the metropolitan of Pamiers and hence the only authority legally empowered to act against Saisset. Because of the obedience he owed the Pope, Aycelin refused to support and endorse the King's arrest of his suffragan. Under intense pressure because of the alleged 'enormity' of Saisset's crimes and the urgency of the situation, Aycelin tried to protect himself by arguing that since Senlis was located outside of his province and jurisdiction, it was impossible for him to act there and formally order Saisset's arrest. Philip the Fair's advisers were so eager to secure Archbishop Aycelin's recognition of royal authority in this exceptional ecclesiastical case that, to dissipate his qualms, they proposed the creation of an enclave of the province of

52 The proceedings, including a list of ten articles of accusation, are edited in Dupuy, Histoire du différend, pp. 631-51, and in Gallia christiana, XIII, Instrumenta, cols 120-21. See Vidal, 'Bernard Saisset', pp. 180-81, 372, 380-84.

53 So Saisset later claimed in a text of gravamina (complaints in the form of an appeal) against the royal procedure (ed. in Dupuy, Histoire du différend, pp. 651-53, and in Gallia christiana, XIII, Instrumenta, cols 131-34, at cols 132-33).

54 This text is edited in Martène and Durand, Thesaurus novus anecdotorum, I, cols 1334-36, and (better) in Gallia christiana, XIII, Instrumenta, cols 118-20.

55 This text is edited in Martène and Durand, Thesaurus novus anecdotorum, I, cols 1319-30, and (better) in Gallia christiana, XIII, Instrumenta, cols 107-15.

56 See McNamara, Gilles Aycelin. 
Narbonne in that of Reims, where Senlis lay $!^{57}$ All this in vain: Aycelin refused to budge. Clearly, neither the Bishop of Senlis and the Archbishop of Reims both of whom apparently agreed to the political manoeuvre - nor the King had the power to modify ecclesiastical districts in this way. Such a prerogative was the pope's alone - as Boniface had demonstrated in creating the diocese of Pamiers.

A few days after the council's meeting at Senlis, a memorandum was composed to summarize and justify the measures the King had taken against Saisset, in preparation for an embassy that would present the affair to the Pope and ask for his approval..$^{58}$ When I first examined this crucial document, using Pierre Dupuy's edition, I believed it most likely the work of Pierre Flotte, who appeared to be the person chiefly responsible for royal policies towards the church. ${ }^{59}$ However, Sébastien Nadiras later demonstrated conclusively that the two extant versions of the text were written by Nogaret.

Sane ad audientiam - the document's opening words - begins with a list of the crimes attributed to Saisset. ${ }^{60}$ The Bishop is a 'traitor to his nation, to his lord the King, and to the kingdom of France'; he is 'disobedient and a rebel against the King's jurisdiction and power over the temporalities of his church';

57 Gallia christiana, XIII, Instrumenta, cols 107-15; see also in Sane ad audientiam, ed. by Denton, 'Bernard Saisset', pp. 424-25.

58 Two versions of this text are kept at Paris, AN, J 336, $9^{1}$ and $9^{2}$ (the first clearly is a draft). The editions in Denton, 'Bernard Saisset', pp. 415-26 (with an English translation), and Nadiras, 'Guillaume de Nogaret', II, 790-95, have made obsolete the edition in Dupuy, Histoire du différend, pp. 627-31, which does not refer to the existence of two copies of the act; but these recent editions do not identify the quotations that I discuss here. See also Nadiras, 'Guillaume de Nogaret', I, 111-12; and Elizabeth A. R. Brown's contribution in the present volume, at notes $42-44$.

59 Théry, 'Pouvoir royal et procès politico-religieux'. Digard, Philippe le Bel, II, 81, attributed the text to Flotte.

${ }^{60}$ Denton, 'Bernard Saisset', p. 416: 'Sane [pervenit] ad audientiam excellentis principis domini Philippi Dei gratia Francorum regis, pluries a fide dignis personis quod B., Appamiensis episcopus, proditor patrie sue, domini regis et regni Francie, contra fidelitatem ad quam domino regi tenetur proditiones, conspirationes ac factiones facinorosas contra ipsum dominum regem et ejus honorem concepit, tractavit et multis modis inhivit ; quodque idem episcopus ex proditionis hujus conceptu, jurisdictioni et potestati regie super temporalitate ecclesie sue erat inobediens et rebellis honorique regio verbis et factis existens, ad blasphemias, contumelias ipsius domini regis et injurias prorumpebat, et curiam suam coram diversis personis quantum poterat gravissime diffamabat, domino regi auferendo corda et bonam voluntatem eorum, hominesque nobiles et plebeyos terrarum ipsarum, quantum poterat, provocabat ad rebellandum contra dominum regem predictum, ita quod dictus dominus rex terram perderet Tholosanam. 
he insulted the king and uttered 'blasphemies' against him; ${ }^{61}$ he 'took from the King both the hearts and the good will' of the inhabitants of Toulouse and its region in order to 'push them to rebel'. The text quickly becomes a semi-pastiche of phrases from mandates commonly issued by the popes since the beginning of the thirteenth century to launch judicial proceedings against delinquent prelates. ${ }^{62}$ Employing a range of papal strategies and arguments, Nogaret cites as the sources that led to discovery of the crimes certain 'credible persons' (fide digne persone) and clamosa insinuatio as well as fama (both meaning public opinion or common knowledge). ${ }^{63}$ Fama and clamosa insinuatio, it should be noted, were key categories in the eighth canon of the Fourth Lateran Council (1215), Qualiter et quando, a critically important text that stipulated the rules of inquisitorial procedure, ${ }^{64}$ and also in the decretal Inquisitionis negocium, another important text issued by Innocent III $^{65}$ - and they were thus commonly men-

61 The notion of 'blasphemy' against the King — which was rare for the time, the term having been since Late Antiquity almost always reserved for offences against God - was dear to Nogaret, it seems. Indeed, one comes across it in another text positively attributed to him by Sébastien Nadiras: a draft of a charter of franchise for the inhabitants of Figeac (Nadiras, 'Guillaume de Nogaret', II, 671). This is yet another example, one to add to the host of others presented below, of the transposition of a principally religious notion into the royal sphere. On this aspect in general, see Théry-Astruc, "Les Écritures ne peuvent mentir"'.

62 Théry, 'Fama: L'opinion publique comme preuve juidiciaire'; Théry-Astruc, “Excès”, "affaires d'enquête”'; Théry-Astruc, 'Judicial Inquiry'.

${ }^{63}$ Denton, 'Bernard Saisset', pp. 418-9: 'Crebro sermone ac clamosa insinuatione fidelium suorum rumor premissorum aures domini regis ipsius intonuit. [...] Prefatis igitur inquisitoribus propter hoc in Tholosanis partibus constitutis, fama referente, et nichilominus a fide dignis personis premissa omnia et singula que ad dominum regem clamosa insinuatione pervenerant dictis inquisitoribus significata fuerunt'.

${ }^{64}$ X, 5, 1, 24; Friedberg, Corpus iuris canonici, II, col. 745: 'Non solum quum subditus, verum etiam quum prelatus excedit, si per clamorem et famam ad aures superioris pervenerit, non quidem a malevolis et maledicis, sed a providis et honestis, nec semel tantum, sed sepe, quod clamor innuit et diffamatio manifestat, debet coram ecclesie senioribus veritatem diligentius perscrutari, ut, si rei poposcerit qualitas, canonica districtio culpam feriat delinquentis, non tanquam idem sit accusator et judex, sed quasi denunciante fama vel deferente clamore officii sui debitum exsequatur. [...] Sicut accusationem legitima debet precedere inscriptio, sic et denunciationem caritativa monitio, et inquisitionem clamosa insinuatio prevenire'. On Qualiter et quando, the setting up of inquisitorial procedure and the role of fama, see Trusen, 'Der Inquisitionsprozeß'; Fraher, 'IV Lateran's Revolution', pp. 107-09; Théry, 'Fama: L'opinion publique comme preuve judiciaire', pp. 127-30; Fiori, 'Quasi fama denunciante'.

${ }^{65} \mathrm{X}, 5,1,21$; Friedberg, Corpus iuris canonici, II, col. 742: 'Respondemus nullum esse pro crimine, super quo aliqua non laborat infamia, seu clamosa insinuatio non processerit. [...] Quesivisti etiam, quid statui debeat, si nihil per certam scientiam, sed tantum per famam, et 
tioned in papal letters of inquiry against prelates. ${ }^{66}$ The King, Nogaret explains, at first refused to believe the Bishop could have committed such terrible crimes and wanted to 'cover them up' (potius dissimulavit predicta). But the rumours took on such proportions that he ultimately concluded he would be blamed for 'negligence' if he tried to hide them any longer (si amplius premissa dissimularet) and did not act ${ }^{67}$ - and this was, again, a very ecclesiastical way of putting things.$^{68}$ Thus Philip the Fair determined 'to go down and see' in order to 'inform his conscience, ${ }^{69}$ that is to say, he sent investigators out in order to discover the

eorum, qui fuerint inquisiti, credulitatem juratam contigerit inveniri'. The fide digne persone mentioned by Nogaret in Sane ad audientiam (see also further in the text, Denton, 'Bernard Saisset', p. 420: 'Item a plerisque personis fide dignis et gravibus ad dictum dominum pervenit') correspond to the providi et honesti mentioned in Qualiter et quando and to the boni et graves mentioned in Inquisitionis negocium.

${ }^{66}$ Among many occurrences, see Les registres d'Innocent $I V$, ed. by Berger, no. 584 ('deferente siquidem ad aures nostras clamosa insinuatione per fidedignos sepius inculcata quod quondam Vigintimiliensis episcopus symonia, incontinentia et aliis criminibus irretitus'); Les registres d'Urbain $I V$, ed. by Guiraud and Clémencet, no. 743 ('nuper, fama immo verius infamia clamante publica et clamore diffamante, ad nostrum pervenit auditum quod'); Les registres de Nicolas III, ed. by Gay and Vitte-Clémencet, no. 310 ('ad audientiam vestram insinuatio clamosa perduxit quod venerabilis frater noster O. episcopus Narniensis luride dissolutionis dilapsus').

${ }^{67}$ Denton, 'Bernard Saisset', p. 418: 'Nolens etiam idem dominus rex esse facilis ad credendum, nullo modo cor suum movere poterat ad credendum quod dictus episcopus, sic patrie dignitatem et ecclesie sue ac salutis proprie et beneficiorum susceptorum immemor, tanta ingratitudine teneretur, ut aliquatenus acceptasset etiam cogitare aliquid predictorum ; sed potius idem dominus rex magno tempore dissimulavit predicta, donec sibi crebro sermone ac clamosa insinuatione fidelium suorum rumor premissorum aures domini regis ipsius intonuit, quod notabiliter ad ejus culpam et honoris regii gravem negligentiam notabiliter posset et deberet ascribi si amplius premissa dissimulasset'.

${ }^{68}$ See the canon Qualiter et quando (X, 5, 1, 24; Friedberg, Corpus iuris canonici, II, col. 746: 'Cum super excessibus suis quisquam fuerit infamatus, ita ut iam clamor ascendat, qui diutius sine scandalo dissimulari non possit vel sine periculo tolerari, absque dubitationis scrupulo ad inquirendum et puniendum ejus excessus, non ex odii fomite, sed caritatis procedatur affectu'), and, among many occurrences, Die Register Innocenz'III, II, ed. by Hageneder and others, no. 227, pp. 434-36 ('ad corrigendos ergo subditorum excessus tanto diligentius debet prelatus assurgere, quanto damnabilius correctionem eorum negligeret'); Théry, 'L'Église, les Capétiens et le Languedoc', p. 237 (in a letter issued by Pope Alexander IV: 'Nolentes [ista] sub dissimulatione transire, ne incorrecta prestentaudaciam committendi pejora'); Les registres de Boniface VIII, ed. by Digard and others, no.3610 ('nolentes illa, prout etiam nec debemus, sub dissimulatione transire'). See also the letter of inquiry of Urban IV cited below, at note 69.

69 The 'conscience' of the pope and of his judge delegates was a key concept in the decretals and other papal letters of the twelfth and thirteenth centuries. See for instance the decretal 
truth. ${ }^{70}$ Here Nogaret appropriated, word for word, a formula well known to clerics and often used by popes and ecclesiastical judges since Innocent III cited a passage of Genesis at the centre of the canon Qualiter et quando.$^{71}$ In Genesis, the formula is attributed to God himself. Using these words, he declared that he was sending two angels to ascertain the guilt of Sodom before proceeding to punish the Sodomites for their crimes: 'I will go down and see whether they have done according to the cry that is come to me, or whether it be not so, that I may know' (Genesis 18.21; 'Descendam et videbo utrum clamorem qui venit ad me, opere compleverint; an non est ita, ut sciam'). ${ }^{72}$

Qualiter et quando issued by Innocent III in 1206, the text of which was partly included in the eponymous canon of the Fourth Lateran Council (X, 5, 1, 17; Friedberg, Corpus iuris canonici, II, col. 739: 'Mandamus quatenus, ad conscientie vestre judicium recurrentes') and a letter of inquiry issued by Urban IV against the Bishop of Fermo in 1263 (Les registres d'Urbain IV, ed. by Guiraud and Clémencet, no. 733: 'Actus nepharios venerabilis fratris nostri Gerardi, episcopi Firmani, fidedignorum nobis assertione relatos, nos compellit referre conscientia, licet invitos'). In the legal and judicial sphere, 'conscience' was still a typically ecclesiastical notion at the beginning of the fourteenth century. See Padoa Schioppa, 'Sur la conscience du juge'; Helmholz, 'Conscience in the Ecclesiastical Courts'; Murray, Conscience and Authority.

${ }^{70}$ Denton, 'Bernard Saisset', p. 418: 'Descendere voluit igitur et videre primo familiariter ad informandum suam conscientiam dominus rex predictus, propter honorem Ecclesie, et insuper iis secrete perquirere veritatem cum fide dignis personis, ne quousque dictorum facinorum veritas magis ipsi domino regi nota esset, et posset sequi aliqua diffamatio episcopi memorati'.

${ }^{71}$ X, 5, 1, 24; Friedberg, Corpus iuris canonici, II, cols 745-47: 'Qualiter et quando debeat prelatus procedere ad inquirendum et puniendum subditorum excessus, ex auctoritatibus Veteris et Novi Testamenti colligitur evidenter [...]. Et in Genesi Dominus ait: "Descendam et videbo, utrum clamorem, qui venit ad me, opere compleverint". Ex quibus auctoritabibus manifeste probatur quod non solum cum subditus, verum etiam cum prelatus excedit, si per clamorem et famam ad aures superioris pervenerit [...], debet coram ecclesie senioribus veritatem diligentius perscrutari ut, si rei poposcerit qualitas, canonica districtio culpam feriat deliquentis. In 1199 and 1206, Innocent III had already cited this passage of Genesis in two decretals, Licet Heli and Qualiter et quando (X, 5, 1, 17, and 5, 3, 31; Friedberg, Corpus iuris canonici, II, cols 738 and 760), the text of which were later partly included in the eighth canon of the council of Lateran. See also Die Register Innocenz'III, II, ed. by Hageneder and others, no. 227, pp. 434-36. For examples of the use of the formula in papal letters of inquiry, see, among many occurrences, Die Register Innocenz'III, IX, ed. by Hageneder and Sommerlechner, no. 268, pp. 455-56 ('super speculam Domini constitutos, cum ea de personis ecclesiasticis nostris auribus referuntur per que nostrum ministerium blasphematur, nos oportet descendere ac videre, Illius exemplo qui'); Les registres de Nicolas III, ed. by Gay and Vitte-Clémencet, no. 310 ('volentes igitur descendere et videre utrum dictus episcopus hec impleverit actione').

72 These words of Genesis were cited and commented upon by Gregory the Great (Pope from 590 to 604) in his well-known and often copied Moralia in Job $(19,25)$. Through a forged letter attributed to Pope Evaristus, they were cited in the False Decretals (XIX, 25, 45, mid- 
In the introduction to Sane ad audientiam, the King is thus accorded the position of the pope, to whom the curial formulas accorded the place of God. Then Nogaret introduced a novel idea. This idea, significant and fundamental, informed the remainder of the text, just as it would inform the royal policies that unfolded in the following years. He wrote: 'Hic ponantur articuli nedum super quibus testes recepti sunt, sed etiam alii et maxime articuli contra fidem et dominum papam attemptati' ('Here must be copied not only the articles on which witnesses were heard, but also others, and, most important, those [dealing with crimes] against the faith and against the Lord Pope'). ${ }^{73}$ The 'articles on which witnesses were heard' were the ones that had been secretly confirmed before the royal deputies sent in the region of Toulouse in the spring of 1301 (these articles were included in the speech read by Flotte at the opening of the council in Senlis). ${ }^{74}$ On the other hand, the articles 'against the faith and against the Lord Pope' were new. Such accusations had not been mentioned in any of the documents concerning the Saisset affair prepared before the council at Senlis. The text of the articles Flotte read at the meeting, preserved in two slightly different versions, contains no trace of them. ${ }^{75}$ But the two accounts of the council by ecclesiastics who were present do mention that the charge of heresy had been voiced there during the heated oral exchanges. One texts refers to certain 'outrageous comments made against God', the other to 'crimes of a heretical nature' imputed to Saisset. ${ }^{76}$ It thus seems clear that the accusation of heresy

ninth century) and then in Regino of Prüm's Libri synodales (II, c. 311 - beginning of the tenth century) as well as in Ivo of Chartres's Decretum (XIV, 79a - end of the eleventh century) and in Gratian's Decretum (C.2 q.1 c. 20; Friedberg, Corpus iuris canonici, I, col. 448 - mid-twelfth century), which made them particularly familiar to ecclesiastical judges and jurists much before the time of Innocent III. But the use of the citation in the eighth canon of the Fourth Lateran Council gave it a new life and importance in the rhetoric of canon law and ecclesiastical justice.

73 Denton, 'Bernard Saisset', p. 419. In the second version of the text (Paris, AN, J 336, no. $\left.9^{2}\right)$, the last part of the sentence, from 'et maxime articuli', is absent. In the draft, this last part was crossed out.

${ }^{74}$ A copy of the articles is kept at the Archives Nationales de France (J 336, no. 1) and is edited in Dupuy, Histoire du différend, pp. 653-56. Another one, from the archives of the archbishopric of Narbonne, is edited in Martène and Durand, Thesaurus novus anecdotorum, I, cols 1330-34, and in Gallia christiana, xifi, Instrumenta, cols 116-18 (this second copy was probably destroyed during the French Revelution).

75 See above, at note 74 .

76 Gallia christiana, XIII, Instrumenta, col. 110: 'Fecit proponi rex ipse contra dictum episcopum presentem crimina hereseos in genere et proditionis ac seditionis et alia quamplura quam dicebat dictum episcopum commisisse contra regem ac suam regiam majestatem et 
had suddenly been made, orally, during the meeting in Senlis — doubtless by the dedicated defenders of the King who were trying to intimidate Gilles Aycelin.

In Sane ad audientiam, Nogaret proceeded then by enumerating three specific additional charges. First, he accused Saisset of being a 'patent simoniac' and, most important, of having 'disseminated numerous false statements, bordering on heresy, against the Catholic faith'. Thus, Saisset allegedly questioned the value of the sacrament of penance and the prohibition of fornication issued to the clergy. ${ }^{77} \mathrm{Up}$ to this point, Nogaret contented himself with appropriating contemporary clichés concerning supposed heretical beliefs. He then accused Saisset of having called Boniface VIII 'the devil incarnate. ${ }^{78}$ Given the history of the relations between Saisset and Boniface VIII, this accusation is so absurd that it looks like a trial balloon, launched with the intent of finding the best provocations with which to harrass the Pope. Nogaret's third article was the most promising in this respect. Here Saisset was accused of having questioned the grounds for the canonization of St Louis, which, as has been seen, Boniface had proclaimed in 1297. Among other 'blasphemies against God, against the supreme pontiff, and against the entire church', the Bishop of Pamiers had dared to assert that Philip the Fair's grandfather had been consigned to hell. ${ }^{79}$

The traitor to the King thus showed himself to be a heretic as well. His treason was partly heretical and his heresy partly treacherous, for the attack on the sanctity of Louis IX was an attack on both the honour of the Capetian family and the Christian faith. Unhesitatingly, Nogaret proceeded to reap

rempublicam regni sui, necnon quamplura alia enormia, turpia et contumeliosa, que dicebat episcopum dixisse de persona regia et parentibus ejus'; and at col. 119: 'Rex [...] proponi fecit contra venerabilem patrem dominum B. [...] crimina proditionis, seditionis et alia quamplurima enormia et gravissima crimina et delicta, que dicebat ipsum dominum Apamiensem episcopum commisisse contra Deum et suam regiam majestatem et rempublicam regni sui'.

77 Denton, 'Bernard Saisset', p. 420: 'Item a plerisque personis fide dignis et gravibus ad dictum dominum pervenit dictum episcopum, simonacum manifestum, pleraque verba erronea ac heretica contra fidem catholicam seminasse, et specialiter contra penitentie sacramentum, et fornicationem etiam in personis ad sacros ordines promotis non esse peccatum, et multa alia erronea asserendo'.

78 Denton, 'Bernard Saisset', p. 420: 'Item quod dictus episcopus in blasphemiam Dei et hominum pluries dixit sanctissimum patrem dominum Bonifacium summum pontificem esse diabolum incarnatum'.

${ }^{79}$ Denton, 'Bernard Saisset', pp. 420-21: 'Item quod dictus dominus papa contra Deum et veritatem et justitiam canonizaverat beatum Ludovicum sancte memorie regem Francie, qui erat in inferno, ut dixit; quodque multa alia erronea dictus episcopus seminavit et dixit contra fidem, in blasphemiam Dei et summi pontificis et totius Ecclesie'. 
the fruits of this convergence. To do so, he again appropriated for the King a papal formula, this one found in a fundamental text of papal theocracy, the famous letter Vergentis in senium, which Innocent III issued in 1199 and which was included in 1234 in the Liber Extra, the official collection of decretals. In Vergentis in senium, Innocent III equated the crime of heresy with the crime of imperial lèse-majesté as defined by Roman law, declaring that 'it is even more serious to damage the eternal majesty than the temporal majesty. ${ }^{80}$ As a result, the majesty of the popes was elevated above the emperors', whose attributes the papacy had appropriated and Christianized. The ultimate necessity of repressing heresy thus provided a juridical and institutional foundation for theocratic absolutism. ${ }^{81}$ In Bernard Saisset and his crimes, as Nogaret depicted them, the Capetians had found the heretic whose offences could bring about their dynasty's transfiguration - by appropriating to the monarchy the functions of the pope. Indeed, the crimes the Bishop of Pamiers committed against the faith, according to Nogaret, had been

considered by the King more serious than those crimes, presented above, committed against the royal majesty; which should come as no surprise, since 'it is even more serious to damage the eternal majesty than the temporal majesty'. Furthermore, any crime committed against God, the faith, or the church of Rome, the lord King considers a crime committed against himself, who has always been, like his ancestors before him, the special defender of the faith and the honour of the church of Rome. ${ }^{82}$

The comments Nogaret inserted after the quotation from Vergentis in senium reoriented it to favour the Capetian ruler. ${ }^{83}$ Since 'any crime committed against

${ }^{80}$ X, 5, 7, 10; Friedberg, Corpus iuris canonici, II, cols 782-83: 'Cum secundum legitimas sanctiones reis lese majestatis punitis capite bona confiscentur eorum [...], quanto magis qui aberrantes in fide Domini filium offendunt, a capite nostro [...] ecclesiastica debent districtione precidi $[. .$.$] , cum longe sit gravius eternam quam temporalem ledere majestatem'.$

${ }^{81}$ See Hageneder, 'Studien zur Dekretale "Vergentis"; Ullmann, 'The Significance of Innocent III's Decretal Vergentis'; Capitani, 'Legislazione antiereticale'; Kolmer, 'Christus als beleidigte Majestät'; Walther, 'Innocenz III. und die Bekämpfung'; Meschini, 'Validità, novità e carattere della decretale Vergentis'; Chiffoleau, 'Note sur la bulle Vergentis'.

${ }^{82}$ Denton, 'Bernard Saisset', p. 421: 'Que gravius longe dictus dominus rex recipit quam superius expressata que contra regiam majestatem commisit dictus episcopus, nec mirum, cum gravius eternam quam temporalem ledere majestatem; quod insuper in Deum vel fidem vel Romanam Ecclesiam committitur contra se commissum recipit dominus rex predictus, qui et sui progenitores defensores speciales fidei et honoris Romane Ecclesie semper fuerunt'.

${ }^{83}$ We here find a striking confirmation of theses proposed by Mario Sbriccoli and Jacques 
God' was now also 'committed against the king, ${ }^{84}$ the monarch was implicitly placed in a position logically identical to God's, ${ }^{85}$ and somewhat comparable to that of the pope since the time of Gregory VII - a position central to papal theocracy. The theocratic popes suggested that the voice of Christ was speaking through them, that it was their duty to punish any offence against him, and also that any offence against them was an offence against him. ${ }^{86}$

The remainder of Nogaret's memorandum Sane ad audientiam confirms this analysis. Papal syle is imitated and canonical ideas are employed with redoubled intensity, and the very nature of royal power implicitly acquires a religious dimension. According to Nogaret, the doctors and other wise advisers consulted by the King at Senlis judged Saisset's misdeeds 'so overt [...] that they could not be covered up without serious scandal and peril' - a formula typical of the Roman chancery, which Nogaret, again, took directly from the canon Qualiter et quando ${ }^{87}$ Philip the Fair had accordingly intended to prosecute the aforementioned crimes, as it would seem God and justice required.8 ${ }^{88}$

Chiffoleau concerning the role played by the decretal Vergentis in senium in the later development of secular majesties. See Sbriccoli, Crimen Laesae Maiestatis, pp. 346-47; Chiffoleau, 'Sur le crime de majesté, pp. 196-98; Chiffoleau, 'Note sur la bulle Vergentis'. See also the intuitions of Kantorowicz, Frederick the Second, ch. 2.

${ }^{84}$ Nogaret's formula echoes a famous passage of Justinian's constitution Manicheos (C, 1, $5,4)$, 'quod in religionem divinam committitur in omnium fertur injuriam'. This constitution, it should be noted, was cited by Nogaret a bit later, in March 1303, when he accused Boniface VIII himself of heresy (Boniface VIII en procès, ed. by Coste, pp. 111-22, $₫ 10$ ). See also below, at note 97 .

85 On the homology between God and the king, see Kantorowicz, 'Deus per naturam'; Kantorowicz, The King's Two Bodies, pp. 42-86; Guéry, 'Le roi est Dieu'.

86 See for instance Ullmann, 'The Significance of Innocent III's Decretal Vergentis', pp. 734-39; Théry, 'Introduction', pp. 19-20; and Die Register Innocenz'III, I, ed. by Hageneder and others, no. 88, pp. 126-28: 'Qui, cum sit Dominus omnium, habens in vestimento et in femore suo scriptum "Rex regum et Dominus dominantium" [Revelation 16. 19], in nobis honoratur cum honoramur et contemnitur cum contemnimur, ipso testante, qui ait: "Qui vos spernit me spernit et qui me spernit spernit eum qui misit me" [Luke 10. 16]'.

${ }^{87}$ Denton, 'Bernard Saisset', pp. 421-22: 'Dictus ergo dominus rex [adfuit] cum majoribus regni sui apud Silvanectum ad hoc specialiter vocatis. Deliberatione habita diligenti, petito consilio clericorum et laicorum, doctorum et aliorum proborum virorum, fuit ipsi domino regi responsum et constanter consultum, cum predicta sint adeo manifesta, ac etiam per diversas partes regni Francie divulguata, [quod] sine gravi scandalo et periculo non poterant sub dissimulatione pertransiri.' See above, at note 68.

${ }^{88}$ Denton, 'Bernard Saisset', p. 422: 'Igitur dominus rex predictus, premissa prosequi intendens, prout secundum Deum et justitiam viderit faciendum. Compare, for instance, with 
Respectful of ecclesiastical immunity (which is an outright lie), yet compelled to take exceptional measures by the danger and the 'enormity' (enormitas) of the crime (a concept derived from papal law, as I have shown), ${ }^{89}$ the King had called on the Archbishop of Narbonne to arrest the criminal Bishop. The ambassadors sent to Boniface VIII should emphasize that the Capetian king 'could and should have had eradicated from his kingdom by having him executed such a traitor convicted before him, like a rotten member, to prevent him from corrupting the other parts of the body.9 ${ }^{90}$ This statement of Nogaret's echoes an old formula for excommunication, which was already common in the early Middle Ages, ${ }^{91}$ and which draws on the even older Christian figure of the body politic, which must be protected against corruption (thus recalling St Augustine's invocation of 'the vile part that is not in harmony with its whole', which Nogaret cited in at least one extant text, as I showed above). The kingdom of France is thus identified as a church in the literal sense of the term, a society of believers. The image of Christendom as a mystical body, which theocratic popes had revived to bolster their power, was here transferred to a national entity. ${ }^{92}$

The text then becomes biblical and apocalyptic in tone. Saisset is termed a vir mortis, a 'man of death', the phrase King Salomon used to describe the priest Abiathar, according to the Bible, when he stripped him of his religious functions (I Kings 2. 26). References to the religious powers exercised by the kings of the Old Testament before Christ had founded his church would reappear often in texts written by Nogaret or other royal advisers during the years

Les registres de Grégoire IX, ed. by Auvray, no. 686 ('ut [...] procedamus prout secundum Deum viderimus procedendum') and with Les registres de Grégoire X, ed. by Guiraud, no. 418 ('prout secundum Deum expedire videbitis procedatis').

89 Théry, 'Atrocitas/enormitas'.

90 Denton, 'Bernard Saisset', pp. 424-25: 'Adiciens quod licet dominus rex de magnorum consilio conveniret quod tantum et talem proditorem suum, coram se convictum, posset et deberet statim supplicio ipsum tradendo de medio tollere regni sui, sicut membrum putridum, ne ceteras corporis partes corrumpat, cum tantus reatus omne privilegium, omnem dignitatem excludat'.

91 We find it for example in Regino of Prüm (Reginonis abbatis, ed. by Wasserschleben, pp. 371, 373-74: 'Membrum putridum et insanabile quod medicinam non recipit ferro excommunicationis a corpore ecclesie abscidanus, ne tam pestifero morbo reliqua membra corporis veluti venono inficiantur').

92 See de Lubac, Corpus mysticum; Kantorowicz, The King's Two Bodies, pp. 194-232 (but, as I have suggested, Kantorowicz dates too early the phenomenon of the sacralization of the body politic, which didn't occur in France before Nogaret: see Théry, 'A Heresy of State', pp. 136 and 146, nn. 85-86); Krynen, L'empire du roi, pp. 242-51. 
to come, particularly in connection with the Templar affair, ${ }^{93}$ to justify the role assumed by Philip the Fair in the religious arena. Here Nogaret drew above all on the rhetoric the church deployed against heresy in order to decry the threat the Bishop of Pamiers posed to the entire kingdom: Saisset's mere existence is 'a horrible outrage' (enormitas horribilis) which 'corrupts the place where he lives'. He is a being 'so vile that to him all elements should default by death, for he is an offence to God and every creature alike. ${ }^{94}$ The same vocabulary and themes appear in the preamble to Vergentis in senium, ${ }^{95}$ and also in at least two other major papal pronouncements against heretics from the beginning of the thirteenth century, the bulls Si adversus nos $(1205)^{96}$ and Vox in rama (1233). ${ }^{97}$

The appropriation of papal language ultimately led, in Sane in audientiam, to a redefinition of the relations between the papacy and the Capetian monarchy, to the distinct benefit of the King. To be sure, in his concluding remarks Nogaret conceded that the Pope was 'God's lieutenant on earth'. But this resulted in no limitation on the King's sphere of action. To the contrary,

${ }^{93}$ Le dossier de l'affaire des Templiers, ed. by Lizerand, pp. 58, 64, 98, 100.

${ }^{94}$ Denton, 'Bernard Saisset', pp. 425-26: 'Requiritque dictus dominus rex ipsum summum pontificem ut super premissis sic celere remedium adhibeat, sic debitum officii sui exerceat, ut dictus vir mortis, ex cujus vita locus etiam quem inhabitat per ipsius enormitatem horribilem corrumpitur, omni ordine suo privet[ur], omni privilegio suo exuat[ur] clericali, quod suum est tollat[ur], ita quod dominus rex de illo proditore Dei et hominum in profundo malorum posito, de quo aliqua correctio vel vite emendatio sperari non potest, cum a juventute sua semper male vixerit et ad inveteratam consuetudinem, turpitudinem et perditionem suam deduxisse noscatur, possit Deo facere per viam justicie sacrificium optimum ; tantum enim nequam est quod omnia debent sibi elementa deficere in morte, qui Deum omnemque creaturam offendit'.

95 X, 5, 7, 10; Friedberg, Corpus iuris canonici, II, col. 782: 'Vergentis in senium seculi corruptelam non solum sapiunt elementa corrupta, sed etiam dignissima creaturarum, prelata privilegio dignitatis volucribus celi et bestii universe terre testatur, nec tantum eo quasi deficiente jam deficit, sed et inficit et inficitur scabra rubigine vetustatis'.

96 X, 5, 7, 11; Friedberg, Corpus iuris canonici, II, cols 783-84: 'Si adversus nos terra consurgeret et iniquitates vestras celi sidera revelarent et manifestarent vestra scelera toti mundo, ut non solum homines, sed ipsa etiam elementa conjurarent in vestrum excidium et ruinam et a terre facie vos delerent [...], ultio de vobis sumi non posset sufficiens sive digna'.

${ }^{97}$ Epistolae saeculi XIII, ed. by Rodenberg, I, no. 537, pp. 433-34: 'Contra quam [speciem heresis] ipsa etiam elementa debent insurgere et armari'. The phrase 'in profundo malorum positus' found in the passage of Sane ad audientiam cited above, at note 94, appears in Lapis abscissus, a letter issued by Pope Boniface VIII against the Colonna in 1297 (Les registres de Boniface VIII, ed. by Digard and others, no. 2389). The end of the same passage echoes Justinian's constitution Manicheos (C, 1, 5, 4: 'Quod in religionem divinam committitur in omnium fertur injuriam') - see above, at note 84 . 
the King gained rights as regarded the Pope, and the Pope now incurred obligations as regarded the King. Papal jurisdiction could not limit the King's actions against Saisset because of the Bishop's treason and heresy, crimes of such enormity that they 'annulled all privilege or dignity', and thus every claim to ecclesiastical immunity. ${ }^{98}$ That the Capetian King had not had the criminal executed was out of deference to the church. According to Nogaret, Philip the Fair was not, in any case, asking Boniface VIII to judge Saisset. Rather, the King was 'notifying' the Pope of the facts ('premissa significat ipsi summo pontifici'), as if they had already been established by a royal judgement (Saisset had been 'convicted before him', 'coram se convictum'), and was 'demanding that the Pope execute his office' by degrading the Bishop so that he could be put to death. In this emergency situation, the Pope was indeed 'bound to punish not only the offence against God, but also that against the lord King, his son, and the entire kingdom. ${ }^{99}$ In this imperious tone, Nogaret implicitly claimed for the Capetian king supreme responsibility in a matter of faith: since his entire kingdom was exposed to the contagion of heresy, the King had the right to demand that the Pope degrade the criminal, and the Pope had the obligation to permit the administration of salutary punishment. The protection of the Christian community against any blow to the unity of the faith, on which the popes founded their theocratic claims, could now be the foundation of a theocratic monarchy. In short, turning a traitor into a heretic, Nogaret also turned the King into God's representative. This was the breakthrough brought about by Sane ad audientiam.

The conflict between Philip the Fair and the papacy that was initiated by the Saisset affair soon continued and escalated in the form of two other causes célè-

98 Denton, 'Bernard Saisset', p. 425: 'Cum tantus reatus omne privilegium, omnem dignitatem excludat'.

99 Denton, 'Bernard Saisset', pp. 424-25: 'Licet dominus rex de magnorum consilio conveniret quod tantum et talem proditorem suum, coram se convictum, posset et deberet statim supplicio ipsum tradendo [cf. C, 1, 5, 5] de medio tollere regni sui sicut membrum putridum, ne ceteras corporis partes corrumpat, cum tantus reatus omne privilegium, omnem dignitatem excludat [cf. C, 9, 8, 4], licet insuper contra dictum episcopum dictus dominus rex aliis viis potuisset procedere ad finem privationis temporalitatis, quam idem episcopus tam ex se quam ratione ecclesie Appamiarum noscitur possidere; ipse tamen dominus rex, progenitorum suorum sequens vestigia, qui privilegia et libertates ecclesie sue voluerunt servare, honoremque Romane ecclesie matri, de cujus uberibus sunt lactati, usquequaque servare, premissa significat ipsi summo pontifici patri suo, qui nedum Dei injuriam, cujus locum tenet in terris, sed etiam dicti domini regis, filii sui, et totius regni sui, vindicare tenetur; requiritque dictus dominus rex ipsum summum pontificem ut super premissis sic celere remedium adhibeat, sic debitum officii sui exerceat'. 
bres - the attack on Boniface VIII, and then the trial of the Templars. These subsequent affairs played out the programme that Nogaret had principally initiated, a programme which the memorandum Sane ad audientiam traces out in broad outline: the Capetian King was to be substituted for the Pope as Christ's deputy and as supreme defender of the faith.

Predictably, Boniface VIII reacted harshly to Philip the Fair's prosecution of Saisset. ${ }^{100}$ In a series of bulls issued on 4, 5, and 6 December 1301, he urged the King to release Saisset from custody (otherwise Philip would 'offend the divine majesty'); ${ }^{101}$ he announced the suspension of the privileges granted to the King in recent years, ${ }^{102}$ and he summoned the French bishops to a synod to be held in Rome in the fall of 1302 to pass judgement on Philip's actions and to discuss the good governance of the realm, ${ }^{103}$ which amounted to gross interference in the monarchy's internal affairs. ${ }^{104}$ In the bull Ausculta fili - the beginning of which imitated the Rule of St Benedict, suggesting provocatively, as Tilmann Schmidt has shown, that the Pope exercised over the King the same absolute power as that of an abbot over one of his monks ${ }^{105}-$ Boniface also reminded Philip that the Pope was his superior and went so far as to threaten his deposition. He invited him to appear personally at the Curia, or to send delegates, to defend his case and to ultimately hear 'what our Lord God says through us', that is, the Pope's judicial sentence regarding the King's misdeeds, to be pronounced at the end of synod of the French bishops. He concluded by recommanding Philip to do penance and to reform himself, 'so that you will

100 See Digard, Philippe le Bel, II, 82-92; Paravicini Bagliani, Boniface VIII, pp. 303-07, Brown, 'Unctus ad executionem justitie', pp. 150-51; Les registres de Boniface VIII, ed. by Digard and others, no. 4422-24, 4426, 4432.

${ }^{101}$ Les registres de Boniface VIII, ed. by Digard and others, no. 4432: 'Habiturus te taliter in premissis quod majestatem non offendas divinam nec Sedis apostolice dignitatem'.

${ }^{102}$ Les registres de Boniface VIII, ed. by Digard and others, nos. 4422-23.

${ }^{103}$ Les registres de Boniface VIII, ed. by Digard and others, no. 4426: 'Universitatem verstram $[\ldots]$ rogamus et hortamur attente $[\ldots]$ quatinus $[\ldots]$ vos $[\ldots]$ nostro vos conspectui presentetis ut super premissis [...] possimus [...] tractare, dirigere, statuere, procedere, facere et ordinare que ad honorem Dei et apostolice Sedis, augmentum catholice fidei, conservationem ecclesiastice libertatis ac reformationem regis et regni, correctionem preteritorum excessuum et bonum regimen regni ejusdem viderimus expedire'. On this bull, see Kay, 'Ad Nostram Presentiam Evocamus'.

${ }^{104}$ As Eugenio Dupré-Theiseder has emphasized; see Dupré-Theseider, 'Bonifacio VIII', p. 159.

105 Schmidt, 'La condamnation de Pierre Flote', pp. 112-13. 
not appear to God's judgement and ours, which depends on it, in such a state that you should be condemned.'. 106

At this stage, the Saisset affair was no longer, in itself, a major issue. On 13 January 1302, Boniface VIII launched an inquiry into Saisset's alleged crimes and appointed Archbishop Gilles Aycelin, the Bishop of Béziers, and the Bishop of Maguelonne as investigators. The papal mandate only mentioned the charges that Flotte had presented at the council of Senlis; no reference whatsoever was made to crimes against the faith. ${ }^{107}$ We cannot be sure that Nogaret's additional articles of accusation in Sane ad audientiam were actually presented to the Pope. If they were - as is probable, since Sane ad audientiam was a note of instruction for the royal envoys to the Pope - Boniface chose to ignore them. In opening a traditional ecclesiastical procedure of inquiry against Saisset, the Pope's aim was only to give the King minimum satisfaction, so as to obtain Saisset's release from custody. ${ }^{108}$ We know that the Bishop was on his way to Rome in February 1302. ${ }^{109}$ Unsurprisingly, it seems that no other step was ever taken in this papal procedure. The inquiry was most probably dropped shortly after Saisset reached the Curia. Saisset came back to Pamiers and started to govern his diocese normally again at the end of 1305 . He then had normal

${ }^{106}$ Les registres de Boniface VIII, ed. by Digard and others, no. 4424: 'Fili carissime, nemo tibi suadeat quod superiorem non habeas et non subsis summo ierarche ecclesiastiche ierarchie. [...] Si tuam itaque rem agi putaveris, eodem tempore per te vel fideles viros et providos tue conscios voluntatis ac diligenter instructos, de quibus plene valeas habere fiduciam, hiis poteris interesse, alioquin, tuam vel ipsorum absentiam divina replente presentia, in premissis et ea contingentibus [...] procedemus. Tu autem audies quid loquetur in nobis Dominus Deus noster. [...] Sic te prepares in premissis et aliis, sic reformes, quod ad judicium Dei et nostrum, ab illo dependens, non damnandus accedas'.

107 Les registres de Boniface VIII, ed. by Digard and others, no. 4269.

108 Schmidt, 'La condamnation de Pierre Flote', p. 112, misinterprets Boniface's mandate of inquiry against Saisset and the Pope's general attitude in the whole Saisset case. In his mandate of inquiry, the Pope doesn't criticize Saisset's attitude, as Schmidt has it, but simply uses the ordinary formulas (on the traditional papal investigations into the excessus of the prelates, which never included charges of heresy, see Théry-Astruc, "'Excès", "affaires d'enquête”; Théry-Astruc, 'Judicial Inquiry'). In the bull Super Petri solio, which solemnly pronounced Philip the Fair's excommunication and should have been published on 8 September 1303, Boniface mentioned the King's wrong actions against Saisset, which dearly shows that the Pope never was taken in by the royal accusations against the Bishopeof Pamiers (Dupuy, Histoire du différend, pp. 182 and 185: 'Ad hec, ut omittamus de [...] eo quod quondam in persona venerabilis fratris nostri B., Appamiarum episcopi, temerarie actum extitit'; 'ut taceamus ad presens de [...] temerariis actibus in jamdictum commissis episcopum').

109 Digard, Philippe le Bel, II, 96. 
relations with Philip the Fair - which confirms that the accusations of treason (let alone those of heresy) in 1301 were only instrumental. ${ }^{110}$

After Boniface issued Ausculta fili and the other bulls of 4-6 December 1301, the conflict developed at a higher level. On 10 April 1302, Pierre Flotte responded to Boniface with a new provocation: he read a false and outrageous version of Ausculta fili before a large assembly at Notre-Dame in Paris (which is traditionally seen as the first 'États généraux'), and proclaimed that the King of France, who held his kingdom only from God, had no superior in temporal affairs. Two and a half months later, in a consistory held on 25 June, Boniface VIII warned the envoys sent by Philip the Fair that he would not hesitate to depose their master if necessary, just as three kings of France had already been deposed by past popes. Only half of the French bishops dared to come to the Roman synod, given a prohibition issued by Philip. The meeting was not followed by any specific declaration, but on 18 November, Boniface VIII issued the bull Unam Sanctam, which reaffirmed the general principles of papal theocracy to an extreme degree: 'Secular authority should be submitted to the spiritual one'; 'if a secular power deviated', it should be 'judged by the spiritual power'; anyone who resisted the spiritual power set by God 'resisted God's order'; therefore 'all human creatures must be submitted to the Roman pontiff by necessity of Salvation.' ${ }^{111}$ Six days later, on 24 November, Boniface sent

110 Saisset had to accept a significant reduction of the temporalities of his cathedral and, on 23 July 1308, at Poitiers, he signed with Guillaume de Nogaret an agreement that gave to the King a large share of the cathedral's lordship on lands outside Pamiers. On this occasion Philip the Fair took 'his dear and faithful subject Bernard' under his protection (de Vic and Vaissete, Histoire générale de Languedoc, ed. by Dulaurier and others, x, cols 476-78; see Casimir Barrière-Flavy, Le paréage de Pamiers; Vidal, 'Bernard Saisset', pp. 51-55). On 8 January 1309, the King even wrote to Pope Clement V to dissuade him from launching an inquiry into Saisset's alleged embezzlement ('dilapidatio et alienatio bonorum ecclesie sue'). In his letter, Philip mentioned that in Lyons, in November 1305, Clement had urged him to reconcile with Saisset: 'Meminimus quod Lugduni pia vestra paternitas in Domino exortavit ut B., episcopum Appamiensem, nobis reconciliare necnon ipsum et ejus ecclesiam recommendatos habere vellemus. Exortacionis obtentu, paternis beneplacitis satisfacere cupientes, ipsum, licet nobis immeritum, utpote qui nos offenderat sicut vos credimus non latere, ad gratiam et misericordiam recepimus favorabiliter, gratiose et extunc tanquam devotum, dilectum et fidelem nostrum, illius amore, cujus misericordia superexaltat judicium, et vestri, qui suus estis vicarius, hactenus tractavimus et tractamus, ipsum, ejus ecclesiam et bona recommendatos habentes' (de Vic and Vaissete, Histoire générale de Languedoc, ed. by Dulaurier and others, $\mathrm{x}$, cols 481-82; see Vidal, 'Bernard Saisset', pp. 54-55, 197-98).

${ }^{111}$ Les registres de Boniface VIII, ed. by Digard and others, no. 5382: 'Oportet autem gladium esse sub gladio et temporalem auctoritatem spirituali subici potestati. [...] Si deviat 
Cardinal Jean Lemoine to Philip with a list of claims and a mandate to absolve the King of an excommunication which weighed upon him, 'according to what the pope had understood from credible persons', but Philip would have to ask for this absolution, and thus acknowledge his guilt. ${ }^{112}$ Soon, on 12 March 1303, Nogaret raised the stakes by charging Boniface himself with heresy. With unprecedented audacity, the legist thus declared the see of Christ's vicar empty. Nogaret called upon Philip the Fair to save the church by summoning an ecumenical council to judge the heretical Pope. In the list of accusations he read before an assembly at the Louvre, Nogaret presented the King as an 'angel of God', divinely appointed to punish the lapses from the faith of the person who should have been its supreme guardian:

I beseech you, excellent prince, lord Philip, king of the French by the grace of God, that - just as long ago the angel of the Lord, 'with his sword drawn, placed himself in the road' [Num. 22.31] before the prophet Balaam, when Balaam stepped forward to curse the Lord's people - you, who have been anointed to execute justice, as an angel of the Lord, minister of power and of your office, oppose yourself, with sword drawn, to this bearer of an impious plague who is worse than Balaam, and prevent him from committing the crimes against the people that he intends to carry out. ${ }^{113}$

terrena potestas, judicabitur a potestate spirituali, sed si deviat spiritualis minor, a suo superiori. Si vero supprema a solo Deo, non ab homine poterit judicari, testante Apostolo: "Spiritualis homo judicat omnia, ipse autem a nemine judicatur". Est autem hec auctoritas, etsi data sit homini et exerceatur per hominem, non humana, sed potius divina potestas, ore divino Petro data, sibique suisque successoribus in ipso Christo, quem confessus fuit petra firmata, dicente Domino ipsi Petro: "Quodcumque ligaveris" et cetera. Quicumque igitur huic potestati a Deo sic ordinate resistit Dei ordinationi resistit, nisi duo sicut Maniceus fingat esse principia, quod falsum et hereticum judicamus. Quia testante Moyse, non in principiis, sed in principio, celum Deus creavit et terram. Porro subesse Romano Pontifici omni humane creature declaramus, dicimus, et diffinimus omnino esse de necessitate salutis. On the events of 1302, see Digard, Philippe le Bel, II, 93-142; Paravicini Bagliani, Boniface VIII, pp. 307-36; Schmidt, 'La condamnation de Pierre Flote'; Brown, 'Unctus ad executionem justitie', pp. 152-58.

${ }^{112}$ Les registres de Boniface VIII, ed. by Digard and others, no. 5382: 'Cum te ad partes Francie, certis tibi commissis negotiis, fiducialiter destinemus et intellexerimus, referentibus fidedignis, quod princeps magnificus Phylippus, rex Francorum illustris, excommunicationis est vinculo innodatus, absolvendi regem ipsum, cum ab eo fueris requisitus, juxta formam Ecclesie, a quibuscumque excommunicationum sententiis a canone seu atias, nostra vel predecessorum nostrorum Romanorum Pontificum auctoritate prolatis, quas idem rexcincurrisse dinoscitur, plenam et liberam, presentium auctoritate, concedimus facultatem'. See in particular Brown, 'Unctus ad executionem justitie', p. 154.

113 Boniface VIII en procès, ed. by Coste, p. 115: 'Vobis excellentissimo principi domino Philippo, Dei gratia Francorum regi, supplico ut, sicut angelus Domini prophete Balaam, antiquitus qui ad maledicendum populo Domini procedebat, occurit "gladio evaginato in via", 
At first Philip the Fair hesitated to join such an unprecedented attack. Without responding, he dispatched an embassy that included Nogaret to meet with the Pope. ${ }^{114}$ When this proved fruitless, the King decided to commit himself to Nogaret's plan. In June 1303 he responded positively to an appeal resembling the one Nogaret had made in March, drawn up this time by Guillaume de Plaisians - Nogaret's 'shadow'. Nogaret, who had remained near Rome, could then take action in the name of the King of France, and with military aid from the Pope's Italian enemies. Boniface planned to solemnly declare Philip's excommunication on 8 September with the publication of the bull Super Petri solio, which also annulled all oaths to the King. ${ }^{115}$ But Nogaret and his ally Sciarra Colonna confronted the Pope on 7 September at his residence at Anagni and announced to him that he had been summoned before a general council of the church to answer for his crimes against the faith. ${ }^{116}$

After Boniface's death on 12 October 1303, when Philip the Fair was considering retracting the accusations of heresy against Boniface to normalize relations with his successors, Nogaret deployed his entire arsenal of arguments to convince the King not to abandon his position. In an extraordinary text, to which Elizabeth A. R. Brown has recently drawn attention, the legist summarized the arguments he planned to present to the King, ${ }^{117}$ all supported by quotations from Holy Scripture or the writings of the fathers of the church. Nogaret had been excommunicated by Boniface's successor, Benedict XI, for attacking Boniface at Anagni, which added fire to the reasoning he devised to instruct and even threaten the King. Citing the Gospel of Luke (9.62), for example, Nogaret asserted that 'he who puts his hand to the plow in the service of Christ [in context, to defend the faith against a heretical pope] is not fit for the kingdom of God if he turns back of his own will'. ${ }^{118}$ ' $\mathrm{He}$ who feigns the reli-

sic dicto pestifero, qui longe pejor est dicto Balaam, vos, qui unctus estis ad executionem justicie et ideo angelus Dei, minister potestatis et officii vestri, gladio evaginato occurrere velitis, ne possit malum populi perficere quod intendit'.

114 Coste, 'Les deux missions de Guillaume de Nogaret'.

115 Dupuy, Histoire du différend, pp. 182-86.

${ }^{116}$ Fawtier, 'L'attentat d’Anagni'; Fedele, 'Per la storia dell'attentato'; Paravicini Bagliani, Boniface VIII, pp. 373-88.

117 This text is edited in Holtzmann, Wilhelm von Nogaret, pp. 253-55, and in Brown, 'Moral Imperatives and Conundrums of Conscience', pp. 33-36.

118 Brown, 'Moral Imperatives and Conundrums of Conscience', p. 34: 'Tertio, quod qui ponit manum ad aratrum, hoc est ad Christi neguocium, non est aptus Regno Dei, si sponte retro revertitur'. 
gion and the zeal of God where, in fact, there is neither', Nogaret emphasized, 'makes a mockery of God, and is a hypocrite and liar.' ${ }^{119}$ The impertinence of the legist's statements is striking. He obviously was thinking of addressing these remarks to the King if Philip seemed to be about to abandon his attack against Boniface's memory - which would also have involved abandoning Nogaret's campaign for absolution from the sentence of excommunication that had been imposed on him. Nogaret warned Philip that 'God, according to the Old and New Testaments, destroyed numerous kings and princes for sins like those that have been mentioned', including a king of the Franks, thus alluding to the deposition of Charlemagne's son, Louis the Pious. ${ }^{120}$ Finally, he reminded the King that his decision must be made 'before God and all men', that he 'has no other temporal judge' but only 'God, who cannot be deceived' and 'is bound by the plain truth alone, pure of all deceit'. Since Philip had 'publically taken up Christ's cause and the defence of the church against Boniface', he must 'be careful not to act against the truth and not to render himself a liar in God's eyes. ${ }^{121}$ As if rehearsing a speech he intended to make to the King himself, Nogaret addressed him directly:

Take care not to neglect your reputation [fama] and your honour, and not to scandalize the world by shamefully abandoning your cause, lest you become cruel and sin before all and bring forth scandal and commit mortal sin; and, if you continue, you will always remain in sin and will be unfit for the kingdom of God. No prayers offered on your behalf, nor adverse circumstances, nor any tribulation, will excuse you for abandoning the truth of the Lord, for Holy Scripture cannot lie. ${ }^{122}$

119 Brown, 'Moral Imperatives and Conundrums of Conscience', p. 34: 'Quarto, quod qui fingit religionem et Dei zelum ubi non est Deum derridet, ipocrita est, prevaricator est, et oportet quod talis a Domino neccessario confundatur'.

${ }^{120}$ Brown, 'Moral Imperatives and Conundrums of Conscience', p. 34: 'Septimo advertat regia celsitudo quod Deus in Veteri Testamento et Novo multos reges et principes propter premissa pecata destruxit, sic principes Juda, sic reges gentiles, sic imperatores Romanos, si[c] quendam regem Francorum Ludovicum, sicut imperatorem Fredelicum de suis sedibus exulavit'.

121 Brown, 'Moral Imperatives and Conundrums of Conscience', pp. 34-35: 'Vobiscum ergo est judicium, $\mathrm{O}$ domine rex, coram Deo et hominibus. Non habetis judicem temporalem. Habetis Deum, qui adest et falli non potest, nec flecti muneribus, nec teneri nisi per veritatem simplicem sine duplicitate, palam et publice Christi fidei catolice et defencionis eclesie contra Bonifacium ut dicebatis neguocium assumpsitis. Caveatis ne contra veritatem faciatis nec Deo vos mendacem reddatis, alias veritas vos condempnat. Coram hominibus neguocium assumpsistis, rex estis et tantus'.

122 Brown, 'Moral Imperatives and Conundrums of Conscience', p. 35: 'Cavete ne fama vestram et honorem negliguatis, nec scandalizetis homines vituperiose neguocium dimitendo; 
In this admonition, presented as a sermon, the legist assumed the office of Philip's spiritual advisor.

Nogaret achieved what he wanted. Philip the Fair decided to force the new pope Clement $\mathrm{V}$ to launch a posthumous trial of Boniface, which would imply an acknowledgement of the defunct Pope's heresy (that is, of the failure of a 'vicar of Christ') and of the providentiality of Philip the Fair's intervention. Nogaret conducted this operation, although as an excommunicate he had to rely on his colleague Guillaume de Plaisians when the Pope or his representatives had to be contacted directly. And it was Nogaret once again who, when Clement V balked at pursuing the attack against Boniface's memory, launched another assault on the prerogatives of the papacy by impugning the Order of the Knights Templar. ${ }^{123}$

Philip the Fair's 'discovery' of a 'Templar heresy' that threatened Christendom was aimed at decisively demonstrating the King's superiority over the papacy. The attack also provided an occasion to affirm the Capetian king's calling to defend the French kingdom against the alleged subversive strategies of a so-called heretical sect. ${ }^{124}$ The anti-Templar texts produced by the King's advisers, often by Nogaret himself, are filled with biblical references and rhapsodic celebration of Capetian sacrality and the King's direct relation to God. In his memoranda, Nogaret penned a new chapter of sacred history, featuring as hero the King of France. As Nogaret presented it, the Templars' disavowal of Christ, like their spitting on the crucifix and other sacrilegious acts, were tantamount to renewing Christ's Passion and subjecting him to offences that were 'more serious still than those suffered on the Cross. This was the message of the royal mandate for seizing the Templars, which Nogaret composed after having been made keeper of the seals, on 14 September 1307, ${ }^{125}$ and I showed at the beginning of this essay how Plaisians, in a speech (surely prepared by Nogaret) before

alias crudelis et coram hominibus pecaretis, scandalum generaretis, pecaretis mortaliter et perseverando semper remaneretis in pecato, nec aptus essetis regno Dei; preces presidentis cujusquam vel temporis adversitas vel quevis tribulatio vos excusare non possunt, ut a veritate Domini recedatis; Scripture namque mentire non possunt'.

123 See above, at note 14 .

124 Théry, 'A Heresy of State', pp. 128-37.

${ }^{125}$ Le dossier de l'affaire des Templiers, ed. by Lizerand, p. 18: 'Dominum nostrum Jhesum Christum novissimis temporibus pro humani generis redemptione crucifixum gravioribus quam in cruce pertulit illatis injuriis iterum crucifigunt'. On this mandate and on the way it was executed, see now Field, 'Torture and Confession'; Field, 'Royal Agents and Templar Confessions'. 
the Pope at the consistory of Poitiers, in May 1308, exalted Philip the Fair's victory over the new enemies of Christ, making the King his elected 'minister' and new 'vicar.' ${ }^{26}$ In fact, the crimes imputed to the Knights Templar constituted a heresy of state. ${ }^{127}$ Just as the repression of heretical deviance had allowed the papacy to position itself as a new Christianized imperial power, the persecution of the 'perfidious Templars' provided the Capetian kings with a foundation for their theocratic claims.

It is well known that emancipation from the bonds of ecclesiastical tutelage was generally reached through the sacralization of secular authority. ${ }^{128}$ The intense sacralization of the French monarchy under the reign of Philip the Fair has long been noted, ${ }^{129}$ but its specific form - that of pontificalization - has gone unrecognized.

The genius of Guillaume de Nogaret was to create an osmosis of papal theocracy and Capetian monarchy. This was made possible by the traditional alliance between the two powers but was triggered by the new and violent confrontations pitting them against each other in affairs at once judicial, political, and religious. By appropriating the postures, the rhetorical formulae, and the procedures of the papal monarchy, Nogaret turned this traditional alliance into a deadly embrace and transformed the King of France into a pope in his own realm. ${ }^{130}$ Thus, Nogaret was the pioneering architect of the French 'religion royale' - and therefore of Capetian absolutism.

126 See above, at note 3 .

127 The expression 'heresy of State' was proposed by Jacques Chiffoleau to qualify sorcery and rebellion considered as lèse-majesté. See Chiffoleau, 'L'hérésie de Jeanne', p. 17 and n. 13.

128 See for instance Schmitt, 'Problèmes religieux de la genèse de l'État'.

129 See in particular Kantorowicz, The King's Two Bodies, pp. 249-59; Strayer, 'France'; Lewis, Royal Succession, pp. 133-49; Le Goff, Histoire de la France, pp. 141-46; Krynen, 'Rex christianissimus', p. 92.

${ }^{130}$ See Théry, 'Philippe le Bel'; Théry-Astruc, “'Les Écritures ne peuvent mentir”.' A massive appropriation of papal rhetorics by the French royal chancery (such as the one we saw in Sane ad audientiam) can be observed in the very lastyears of the thirteenth century and in the first years of the fourteenth (see Krynen, “De nostre certaine science”'; Guyotjeannin, 'Traces d'influence pontificale'; Schmidt, 'Der Eintluß der päpstlichen Justizbriefe'). Nogaret clearly played an important part in this phenomenon (which still needs further study), although he officially took the function of chancelor only in 1307. See also Théry, 'A Heresy of State', pp. 34-35, 148. 


\section{Works Cited}

\section{Manuscript and Archival Sources}

Paris, Archives Nationale, J 336, nos. $9^{1}-^{2}$ (memorandum concerning Bernard Saisset, bishop of Pamiers, written by Guillaume de Nangis, and a fine copy of the text)

Paris, Bibliothèque nationale de France, Collection Doat, t. 94, fol. 108

Paris, Bibliothèque nationale de France, fonds latin 10919

\section{Primary Sources}

Amalric Augier, Actus Romanorum pontificum, in Rerum Italicarum Scriptores, III.2 (Milano: Ex typographia Societatis Palatinae, 1734), cols 7-44

Barrière-Flavy, Casimir, Le paréage de Pamiers entre le roi Philippe-le-Bel et l'évêque Bernard Saisset, le 23 juillet 1308 (document publié pour la première fois) (Toulouse: Privat, 1891)

Boniface VIII en procès: Articles d'accusation et dépositions des témoins (1303-1311), ed. by Jean Coste (Roma: L'Erma' di Bretschneider, 1995)

Cartulaire de l'Église Notre-Dame de Paris, ed. by Benjamin Guérard, 4 vols (Paris: Crapelet, 1850)

'A Dispute Between a Priest and a Knight', ed. and trans. by Norma N. Erickson, Proceedings of the American Philosophical Society, 111 (1967), 288-309

Le dossier de l'affaire des Templiers, ed. by Georges Lizerand, Les classiques de l'histoire de France au Moyen Age, 2 (Paris: Les Belles Lettres, 1923)

Epistolae saeculi XIII a regestis pontificum romanorum, ed. by Carolus Rodenberg, MGH, Epistolae saeculi XIII e regestis pontificum romanorum selectae, 3 vols (Berlin: Weidmann, 1883-94)

Martène, Edmond, and Ursin Durand, Thesaurus novus anecdotorum, 5 vols (Paris: Sumptibus F. Delaulne, 1717; repr. Farnburough: Gregg, 1968)

Patrologia latina, ed. by Jacques-Paul Migne, 221 vols (Paris, 1844-55)

Recueil des historiens de la Gaule et de la France, ed. by Martin Bouquet and others, 24 vols (Paris: Victor Palmé, H. Welter, Imprimerie nationale, 1738-1904), xv (1808)

Recueil général des anciennes lois françaises, ed. by Jourdan, Decrusy, Isambert, 29 vols (Paris: Belin-le-Prieur, Verdière, 1822-33)

Reginonis abbatis Prumiensis Libri duo de synodalibus causis et disciplinis ecclesiasticis, ed. by L. W. H. Wasserschleben (Leipzig: G. Engelmann, 1840)

Die Register Innocenz'III, I: Pontifikatsjahr, 1198/99, ed. by Othmar Hageneder and others (Graz, Cologne, 1964)

Die Register Innocenz'III, II: Pontifikatsjahr, 1199/1200, ed. by Othmar Hageneder and others (Roma: Vienne, 1979-83)

Die Register Innocenz'III, IX: Pontifikatsjahr, 1206/1207, ed. by Othmar Hageneder and Andrea Sommerlechner (Roma: Vienne, 2004)

Les registres d'Honorius IV (1285-1287), ed. by Maurice Prou (Paris, 1886-88) 
Les registres d'Innocent IV (1243-1254): Recueil des bulles de ce pape, ed. by Élie Berger (Paris: De Boccard, 1884-1921)

Les registres d'Urbain IV (1261-1264), ed. by Jean Guiraud and Suzanne Clémencet, Bibliothèques des Écoles françaises d'Athènes et de Rome, 2nd ser., 13 (Paris, 1899-1958)

Les registres de Boniface VIII: Recueil des bulles de ce pape publiées ou analysées d'après les manuscrits originaux des Archives du Vatican, ed. by Georges Digard, Maurice Faucon, Antoine Thomas, and Robert Fawtier, 4 vols, Bibliothèques des Écoles françaises d'Athènes et de Rome, 2nd ser., 4 (Paris: E. Thorin, 1921-39)

Les registres de Grégoire IX, ed. by Lucien Auvray, Bibliothèques des Écoles françaises d'Athènes et de Rome, 2nd ser., 9 (Paris, 1890-1955)

Les registres de Grégoire X (1272-1276): Recueil des bulles de ce pape, ed. by Jean Guiraud (Paris, 1892-1960)

Les registres de Nicolas III (1277-1280): Recueil des bulles de ce pape, ed. by Jules Gay and Suzanne Vitte-Clémencet, Bibliothèques des Écoles françaises d'Athènes et de Rome, 2nd ser., 14 (Paris: A. Fontemoing, 1898-1938)

Three Royalist Tracts, 1296-1302, ed. by Robert W. Dyson, Sources in Political Thought (Bristol: Thoemmes Press, 1999)

\section{Secondary Studies}

Barber, Malcolm, The Trial of the Templars, 2nd edn (Cambridge: Cambridge University Press, 2006)

Barbero, Alessandro, 'Bonifacio VIII e la casa di Francia', in Bonifacio VIII: Atti del XXXIX Convegno storico internazionale, Todi, 13-16 ottobre 2002 (Spoleto: Centro italiano di studi sull'alto medioevo, 2003), pp. 273-327

Barthélemy, Dominique, Nouvelle histoire des Capétiens, 987-1214 (Paris: Le Seuil, 2012)

Bautier, Robert-Henri, 'Le jubilé romain de 1300 et l'alliance franco-pontificale au temps de Philippe le Bel et Boniface VIII', Le Moyen Age, 86 (1980), 189-216

Beaune, Colette, The Birth of an Ideology: Myths and Symbols of Nation in Late-Medieval France, trans. by S. R. Huston (Berkeley: University of California Press, 1991)

Berger, Élie, Saint Louis et Innocent IV: Etude sur les rapports de la France et du Saint-Siège (Paris: Thorin, 1893)

Bloch, Marc, The Royal Touch: Sacred Monarchy and Scrofula in England and France, trans. by J. E. Anderson (London: Routledge, 1973)

Bonnassieux, Pierre, De la réunion de Lyon à la France: Étude historique d'après les documents originaux (Lyon: A. de Vingtrinier, 1874)

Briguglia, Gianluca, La questione del potere: Teologi e teoria politica nella disputa tra Bonifacio VIII e Filippo il Bello (Milano: Franco Angeli, 2010)

Briguglia, Gianluca, Claudio Fiocchi, and Stefano Simonetta, Filippo il Bello e Bonifacio VIII: scritti di una diputa (Bergamo: Lubrina, 2002)

Brown, Elizabeth A. R., 'Guillaume de Nogaret et les textes: Les registres JJ 28 et JJ 29 (BnF, lat. 10919)', in La royauté capétienne et le Midi au temps de Guillaume de Nogaret: Actes du colloque des 29 et 30 novembre 2013, ed. by Bernard Moreau and Julien ThéryAstruc (Nîmes: La Fenestrelle, 2015), pp. 209-42 
_ , 'Kings Like Semi-Gods: The Case of Louis X of France', Majestas, 1 (1993), 5-37 , 'Moral Imperatives and Conundrums of Conscience: Reflections on Philip the Fair of France', Speculum, 87 (2012), 1-36

—, 'Unctus ad executionem justitie: Philippe le Bel, Boniface VIII et la Grande Ordonnance pour la réforme du royaume (du 18 mars 1303)', in Le roi fontaine de justice: Pouvoir justicier et pouvoir royal au Moyen Age et à la Renaissance, ed. by Silvère Menegaldo and Bernard Ribémont (Paris: Klincksieck, 2012), pp. 145-68

Burgtorf, Jochen, Paul F. Crawford, and Helen Nicholson, The Debate on the Trial of the Templars, 1307-1314 (Burlington: Ashgate, 2010)

Campbell, Gerard J., 'The Attitude of the Monarchy Towards the Use of Ecclesiastical Censures in the Reign of Saint Louis', Speculum, 35 (1960), 535-55

_ - 'Clerical Immunities in France During the Reign of Philip III', Speculum, 39 (1964), 404-24

—, 'The Protest of Saint Louis', Traditio, 15 (1959), 404-18

—, 'Temporal and Spiritual Regalia During the Reigns of Saint Louis and Philip III', Traditio, 20 (1964), 351-83

Capitani, Ovidio, 'Legislazione antiereticale e strumento di costruzione politica nelle decisioni normative di Innocenzo III', Bollettino della Società di Studi Valdesi, 140 (1976), 31-53

Carolus-Barré, Louis, Le procès de canonisation de saint Louis (1272-1297), essai de reconstitution (Roma: École Française de Rome, 1994)

Charansonnet, Alexis, and Francesco Morenzoni, 'Prêcher sur les reliques de la Passion sous saint Louis', in La Sainte-Chapelle de Paris: Royaume de France ou Jérusalem céleste? (Turnhout: Brepols, 2007), pp. 261-76

Charansonnet, Alexis, Jean-Louis Gaulin, Pascale Mounier, and Susanne Rau, eds, Lyon, entre Empire et royaume (843-1601): Textes et documents (Paris: Classiques Garnier, 2015)

Chiffoleau, Jacques, 'L'hérésie de Jeanne: Note sur les qualifications dans le procès de Rouen', in Jeanne d'Arc: Histoire et mythes. Actes du colloque d'Orléans (9-10 mai 2012), ed. by Jean-Patrice Boudet and Xavier Hélary (Rennes: Presses universitaires de Rennes, 2014), pp. 13-56

— , 'Note sur la bulle Vergentis, la lutte contre les hérétiques et la construction des majestés temporelles', in Innocent III et le Midi, ed. by Daniel Le Blévec, Michelle Fournié, and Julien Théry-Astruc, Cahiers de Fanjeaux, 50 (Toulouse: Privat, 2015), pp. 89-144

— - 'Sur le crime de majesté médiéval', in Genèse de l'État moderne en Méditerranée (Roma: École Française de Rome, 1993), pp. 183-213

Congar, Yves M., 'L'Église et l'État sous le règne de saint Louis', in Septième centenaire de la mort de saint Louis: Actes des colloques de Royaumont et de Paris (Paris: Les Belles Lettres, 1976), pp. 257-71

Coste, Jean, 'Les deux missions de Guillaume de Nogaret en 1303', Mélanges de l'École française de Rome: Moyen Age, 105 (1993), 299-326

Demurger, Alain, La persécution des templiers: Journal (1307-1314) (Paris: Payot, 2015) 
Denton, Jeffrey H., 'Bernard Saisset and the Franco-Papal Rift of December 1301', Revue d'histoire ecclésiastique, 102 (2007), 399-426

- Robert Winchelsey and the Crown, 1284-1313: A Study in the Defense of Ecclesiastical Liberty (London: Cambridge University Press, 1980)

- 'Taxation and the Conflict between Philip the Fair and Boniface VIII', French History, 11 (1997), 241-64

Digard, Georges, Philippe le Bel et le Saint-Siège de 1285 à 1304, ed. by Françoise Lehoux, 2 vols (Paris: Recueil Sirey, 1936)

Dupré-Theseider, Eugenio, 'Bonifacio VIII', in Dizionario biografico degli Italiani (Roma: Istituto della Enciclopedia italiana), pp. 146-70

Dupuy, Pierre, Histoire du differend d'entre le pape Boniface VIII. et Philippes le Bel roy de France (Paris: Chez Cramoisy, 1655)

Dykmans, Marc, Le cérémonial papal de la fin du Moyen Âge à la Renaissance, II (Bruxelles: Institut historique belge de Rome, 1981)

Favier, Jean, Un conseiller de Philip le Bel: Enguerran de Marigny, Mémoires et documents publiés par la Société de l'École des chartes, 16 (Paris: Presses universitaires de France, 1963); repr. in Jean Favier, Un roi de marbre, Quarto (Paris: Fayard, 2005)

Fawtier, Robert, 'L'attentat d'Anagni', Mélanges d'archéologie et d'histoire, 60 (1948 [1949]), 153-79; repr. in Autour de la France capétienne: personnages et institutions, ed. by Jeanne C. Fawtier Stone, Collected Studies Series, 267 (London: Variorum, 1987)

Fedele, Pietro, 'Per la storia dell'attentato di Anagni', Bulletino dell'Istituto storico italiano per il Medio Evo, 41 (1921), 195-232

Field, Sean L., 'Royal Agents and Templar Confessions in the Bailliage of Rouen', French Historical Studies, 39 (2016), 35-71

— , 'Torture and Confession in the Templar Interrogations at Caen, 28-29 October 1307', Speculum, 91 (2016), 297-327

Finke, Heinrich, Papsttum und Untergang des Templerordens, 2 vols, Vorreformationsgeschichtliche Forschungen, 4-5 (Münster: Aschendorff, 1907)

Fiori, Antonia, 'Quasi fama denunciante: note sull'introduzione del processo tra rito accusatorio e inquisitorio', in Der Einfluss der Kanonistik auf die europäische Rechtskultur, III, Straf-und Strafprozessrecht, ed. by Orazio Condorelli, Franck Roumy, and Mathias Schmoeckel (Köln: Böhlau, 2012), pp. 351-67

Fraher, Richard M., 'IV Lateran's Revolution in Criminal Procedure: The Birth of inquisitio, the End of Ordeals and Innocent III's Vision of Ecclesiastical Politics', in Studia in honorem eminentissimi cardinalis Alphonsi M. Stickler, ed. by Rosalius J. Castillo Lara (Roma: Libreria Ateneo Salesiano,1992), pp. 97-111

Friedberg, Emil, Corpus iuris canonici, 2 vols (Leipzig: Tauchniz, 1879-81)

Galland, Bruno, 'La "réunion” de Lyon à-la France: Quarante années pour un rattachement pacifique', in Se donner à la France? Les rattachements pacifiques de territoires à la France, $X I V^{e}-X I X^{e}$ s., ed. by Jacques Berlioz and Olivier Poncet (Paris: École des chartes, 2013), pp. 9-29

Gallia christiana in provincias ecclesiasticas distributa, vol. XIII (Paris, 1785) 
Gaposchkin, M. Cecilia, 'Boniface VIII, Philip the Fair and the Sanctity of Louis IX', Journal of Medieval History, 28 (2003), 1-26

- 'Louis IX and Liturgical Memory', in Memory and Commemoration in Medieval Culture, ed. by Elma Brenner, Meredith Cohen, and Mary Franklin-Brown (Farnham: Ashgate, 2013), pp. 261-78

- The Making of Saint Louis: Kingship, Sanctity and Crusade in the Late Middle Ages (Ithaca: Cornell University Press, 2008)

- 'The Place of the Crusades in the Sanctification of Saint Louis', in Crusades: Medieval Worlds in Conflict, ed. by Thomas F. Madden, James L. Naus, and Vincent Ryan (Farnham: Ashgate, 2010), pp. 195-209

Guéry, Alain, 'Le roi est Dieu; le roi et Dieu', in L'État ou le roi: Les fondations de la modernité monarchique en France (XIV $-X V I I^{e}$ siècle), ed. by Neithard Bulst, Robert Descimon, and Alain Guerreau (Paris: Maison des sciences de l'homme, 1996), pp. $27-47$

Guyotjeannin, Olivier, 'Traces d'influence pontificale dans les actes épiscopaux et royaux français (XIII ${ }^{\mathrm{e}}-\mathrm{XIV}^{\mathrm{e}}$ siècle)', in Papsturkunde und europäisches Urkundenwesen: Studien zu Ihrer formalen und rechtlichen Kohärenz vom 11. bis 15. Jahrhundert, ed. by Peter Herde and Hermann Jakobs (Köln: Böhlau, 1999), pp. 337-64

Hageneder, Othmar, 'Studien zur Dekretale "Vergentis" (X.V,7,10): Ein Beitrag zur Häretikergesetzgebung Innocenz' III.', Zeitschrift der Savigny-Stiftung für Rechtsgeschichte. Kanonistische Abteilung, 49 (1963), 138-73; revised italian translation 'La decretale Vergentis (X. V, 7, 10): Un contributo sulla legislazione antiereticale di Innocenzo III', in Othmar Hageneder, Il sole e la luna: Papato, impero e regni nella teorie e nell prassi dei secoli XII e XIII, ed. by Maria Pia Alberzoni (Milano: Vita \& Pensiero, 2000), pp. 131-63

Hélary, La dernière croisade (Paris: Perrin, 2016)

Helmholz, Richard. H., 'Conscience in the Ecclesiastical Courts', in Proceedings of the Thirteenth International Congress of Medieval Canon Law: Esztergom, 3-8 August 2008, ed. by Peter Erdö and Sabolcs Anzelm Szuromi (Città del Vaticano: Biblioteca Apostolica Vaticana, 2010), pp. 71-84

Henry, Abel, 'Guillaume de Plaisians, ministre de Philippe le Bel', Le Moyen Age, 5 (1892), $32-38$

Holtzmann, Robert, Wilhelm von Nogaret, Rat und Großsiegelbewahrer Philipps des Schönen von Frankreich (Freiburg: J. C. B. Mohr, 1898)

Isaïa, Marie-Cécile, 'Objet du sacre, objet sacré? L'exemple de la sainte ampoule', in Objets sacrés, objets magiques de l'Antiquité au Moyen Age, ed. by Charles Delattre (Paris: Picard, 2007), pp. 151-67

—, Remi de Reims: Mémoire d'un saint, histoire d'une église (Paris: Le Cerf, 2010)

Kantorowicz, Ernst, 'Deus per naturam, Deus per gratiam', Harvard Theological Review, 45 (1952), 121-37; repr. in Selected Studies (Locust Valley: Augustin, 1965)

- Frederick the Second, 1194-1250 (New York: F. Ungar, 1957)

—, The King's Two Bodies: A Study in Medieval Political Theology (Princeton: Princeton University Press, 1997) 
Kay, Richard, 'Ad Nostram Presentiam Evocamus: Boniface VIII and the Roman Convocation of 1302', in Proceedings of the Third International Congress of Medieval Canon Law, Strasbourg, 3-6 September 1968, ed. by Stefan Kuttner (Città del Vaticano: Biblioteca Apostolica Vaticana, 1971), pp. 165-89

Kolmer, Lothar, 'Christus als beleidigte Majestät: Von der Lex Quisquis (397) bis zur Dekretale Vergentis (1199)', in Papsttum, Kirche une Recht im Mittelalter: Festschrift für Horst Fubrmann zum 65. Geburtstag, ed. by Hubert Mordek (Tübingen: Niemeyer, 1991), pp. 1-13

Krynen, Jacques, “"De nostre certaine science ...”: Remarques sur l'absolutisme législatif de la monarchie médiévale française', in Renaissance du pouvoir législatif et genèse de l'État, ed. by André Gouron and Albert Rigaudière (Montpellier: Société d'histoire du droit et des institutions des anciens pays de droit écrit, 1988), pp. 131-44

—, L'Empire du roi: Idées et croyances politiques en France, $X I I I^{e}-X V^{e}$ s. (Paris: Gallimard, 1993)

_- 'Rex christianissimus: A Medieval Theme at the Root of French Absolutism', History and Anthropology, 4 (1989), 79-96

Le Goff, Jacques, Histoire de la France: La longue durée de l'État (Paris: Le Seuil, 1989)

- Saint Louis (Paris: Gallimard, 1996)

Le Roy Ladurie, Emmanuel, Montaillou, the Promised Land of Error, trans. by Barbara Bray (New York: Vintage, 1979)

Lewis, Andrew W., Royal Succession in Capetian France: Studies on Familial Order and the State (Cambridge, MA: Harvard University Press, 1981)

Lubac, Henri de, Corpus mysticum: L'eucharistie et l'Église au Moyen Âge, 2nd edn (Paris: Aubier, 1949)

Maccarone, Michele, Vicarius Christi: Storia del titolo papale (Roma: Lateranum, 1952)

McNamara, Jo Ann, Gilles Aycelin: The Servant of Two Masters (Syracuse: Syracuse University Press, 1973)

Melville, Marion, 'Guillaume de nogaret et Philip le Bel', Revue d'histoire de l'Église de France, 36 (1950), 56-66

Mercuri, Chiara, Corona di Cristo corona di re: la monarchia francese e la corona di spine nel Medioevo (Roma: Edizioni storia e letteratura, 2004)

Meschini, Marco, 'Validità, novità e carattere della decretale Vergentis in senium (Reg. II, 1) di Innocenzo III (25 marzo 1199)', Bulletin of the Medieval Canon Law, 25 (2002-03), 94-113

Michelet, Jules, Histoire de France, vol. III (Bruxelles, 1840)

Moreau, Bernard, ed., Guillaume de Nogaret, un Languedocien au service de la monarchie capétienne (Nîmes: Lucie Éditions, 2012)

Moreau, Bernard, and Julien Théry-Astruc, eds, La royauté capétienne et le Midi au temps de Guillaume de Nogaret (Nîmes: Éditions de la Fenestrelle, 2015)

Murray, Alexander, Conscience and Authority in the Middle Ages (Oxford: Oxford University Press, 2015)

Nadiras, Sébastien, 'Guillaume de Nogaret en ses dossiers: Méthodes de travail et de gouvernement d'un conseiller royal au début du XIV ${ }^{\mathrm{e}}$ siècle' (thèse de doctorat d'histoire, Université Paris 1 Panthéon-Sorbonne UFR 09-Histoire, 2012) 
_- 'Guillaume de Nogaret et la pratique du pouvoir' (unpublished thèse de l'École des chartes, 2003); summary in École nationale des Chartes: Positions des thèses (2003), pp. 161-68

— 'Le tournant décisif (1307-1312): Essai de relecture critique', in Lyon de l'Empire au royaume: Autour du rattachement de Lyon à la France, ed. by Alexis Charansonnet, Jean-Louis Gaulin, and Xavier Hélary (Paris: École des chartes, forthcoming)

Padoa Schioppa, Antonio, 'Sur la conscience du juge dans le ius commune européen', in La conscience du juge dans la tradition juridique européenne, ed. by Jean-Marie Carbasse and Laurence Depambour-Tarride (Paris: Presses universitaires de France, 1999), pp. 95-129

Paravicini Bagliani, Agostino, Boniface VIII: Un pape hérétique?, Biographies Payot (Paris: Payot and Rivages, 2003)

—, Le chiavi e la tiara: Immagini e simboli del papato medievale, La corte dei papi, 3, 2nd edn (Roma: Viella, 2005)

—, Morte et elezione del papa: Norme, riti e conflitti. Il Medioevo (Roma: Viella, 2013)

—_ Il papato nel secolo XIII: Cent'anni di bibliografia (1875-2009), Millenio medievale, 78, Strumenti e testi, 83 (Firenze: SISMEL, Edizioni del Galuzzo, 2009)

- The Pope's Body (Chicago: Londres, 2000)

Pegues, Franklin J., The Lawyers of the Last Capetians (Princeton: Princeton University Press, 1962)

Renan, Ernest, 'Guillaume de Nogaret, légiste', in Histoire littéraire de la France, 27 (1879), 233-371; repr. in Études sur la politique religieuse du règne de Philippe le Bel (Paris: Calmann Lévy, 1899), pp. 1-250

Sbriccoli, Mario, Crimen Laesae Maiestatis: Il problema del reato politico alle soglie della scienza penalistica moderna (Milano: Giuffrè, 1974)

Schimmelpfennig, Bernhard, Die Zeremonialbücher der römischen Kirche im Mittelalter (Tübingen: Niemeyer, 1973)

Schmidt, Hans-Gunther, 'Der Einfluß der päpstlichen Justizbriefe auf die Justizbriefe der französischen königskanzlei um 1300', in Papsturkunde und europäisches Urkundenwesen: Studien zu Ihrer formalen und rechtlichen Kohärenz vom 11. bis 15. Jahrhundert, ed. by Peter Herde and Hermann Jakobs (Köln: Böhlau, 1999), pp. 365-91

Schmidt, Tillmann, Der Bonifaz-Prozess: Verfabren der Papstanklage in der Zeit Bonifaz' VIII. und Clemens' V., Forschungen zur kirchlichen Rechtsgeschichte und zum Kirchenrecht, 19 (Köln: Böhlau, 1989)

_- 'La condamnation de Pierre Flote par le pape Boniface VIII', Mélanges de l'École française de Rome. Moyen Age. MEFRM, 118.1 (2006), 109-21

Schmitt, Jean-Claude, 'Problèmes religieux de la genèse de l'État moderne', in État et Église dans la genèse de l'État moderne: Actes du colloque organisé par le CNRS et la Casa de Velàsquez, ed. by Jean-Philippe Genet and Bernard Vincent (Madrid: Casa de Velàsquez, 1986), pp. 55-62

Strayer, Joseph R., 'France: The Holy Land, the Chosen People, and the Most Christian King, in Action and Conviction in Early Modern Europe, ed. by T. K. Rabb and J. E. Seigel (Princeton: Princeton University Press, 1969), pp. 3-16; repr. in Medi- 
eval Statecraft and the Perspectives of History (Princeton: Princeton University Press, 1969), pp. 300-14

- The Reign of Philip the Fair (Princeton: Princeton University Press, 1980)

Théry, Julien, '1312: Lyon devient française', L'histoire, 379 (2012), 68-73

_- 'Allo scoppio del conflitto tra Filippo il Bello di Francia e Bonifacio VIII: L'affare

Saisset (1301). Primi spunti per una rilettura', in I poteri universali e la fondazione dello

Studium Urbis: Il pontefice Bonifacio VIII dalla Unam sanctam allo schiaffo di Anagni, ed. by Giovanni Minucci, Archivio per la storia del diritto medioevale e moderno, 1 (Roma: Monduzzi, 2008), pp. 21-68

__, 'Atrocitas/enormitas: Pour une histoire de la catégorie de "crime énorme" du Moyen Âge à l'époque moderne', Clio@Themis.Revue électronique d'histoire du droit, 4 (2011), <http://www.cliothemis.com/Clio-Themis-numero-4>

_- 'L'Église, les Capétiens et le Languedoc au temps d'Alphonse de Poitiers: Autour des enquêtes pontificales sur les crimes imputés à Vézian (OFM), évêque de Rodez (1261-1267)', Annales du Midi, 282 (2013), 217-38

_ _ 'Fama: L'opinion publique comme preuve judiciaire. Aperçu sur la révolution médiévale de l'inquisitoire (XII ${ }^{\mathrm{e}}-\mathrm{XIV}^{\mathrm{e}}$ siècles)', in La preuve en justice de l'Antiquité à nos jours, ed. by Bruno Lemesle (Rennes: Presses Universitaires, 2003), pp. 119-47

_- 'A Heresy of State: Philip the Fair, the Trial of the "Perfidious Templars", and the Pontificalization of the French Monarchy', Journal of Medieval Religious Culture, 39 (2012), 117-48

—_, 'Philippe le Bel, pape en son royaume', L'histoire, 289 (2004), 14-17

_ - 'Pouvoir royal et procès politico-religieux sous le règne de Philippe le Bel: directions de recherche' (unpublished mémoire pour le Diplôme d'études approfondies, Université Lumière - Lyon 2, 1998)

—_ 'Procès du Temple', in Prier et combattre: Dictionnaire européen des ordres militaires au Moyen Age, ed. by Nicole Bériou and Philippe Josserand (Paris: Fayard, 2009), pp. 743-50

Théry-Astruc, Julien, “Les Écritures ne peuvent mentir”: Note liminaire pour l'étude des références aux autorités religieuses dans les textes de Guillaume de Nogaret', in La royauté française et le Midi au temps de Guillaume de Nogaret: Actes du colloque des 29 et 30 novembre 2013, ed. by Bernard Moreau and Julien Théry-Astruc (Nîmes: La Fenestrelle, 2015), pp. 243-48

—_, 'Les "États généraux" de Lyon en 1312: Philippe le Bel convoque les consuls de Périgueux', in Lyon, entre Empire et royaume (843-1601): Textes et documents, ed. by Alexis Charansonnet, Jean-Louis Gaulin, Pascale Mounier, and Susanne Rau (Paris: Classiques Garnier, 2015), pp. 375-79

__, “Excès”, "affaires d'enquête” et gourernement de l'Église (v. 1150-v . 1350): Les procédures de la papauté contre les prétats “criminels". Première approche', in La pathologie du pouvoir: crimes, vices et délits-des gouvernants: antiquité, moyen âge, époque moderne, ed. by Patrick Gilli (Leiden: Brill, 2016), pp. 164-236

_- 'Introduction', in Innocent III et le Midi, ed. by Daniel Le Blévec, Michelle Fournié, and Julien Théry-Astruc, Cahiers de Fanjeaux, 50 (Toulouse: Privat, 2015), pp. 11-35 
- 'Judicial Inquiry as an Instrument of Centralized Government: The Papacy's Criminal Proceedings against Prelates in the Age of Theocracy (mid-12th to mid-14th Century)', in Proceedings of the 14th International Congress of Medieval Canon Law (Toronto, 5-11 August 2012) (Città del Vaticano: Biblioteca Apostolica Vaticana, 2016), pp. 875-89

Trusen, Winfried, 'Der Inquisitionsprozeß: seine historischen Grundlagen und frühen Formen', Zeitschrift der Savigny-Stiftung für Rechtsgeschichte, Kanonistische Abteilung, 74 (1988), 171-215

Ullmann, Walter, 'The Significance of Innocent III's Decretal Vergentis', in Études de droit canonique dédiées à Gabriel Le Bras, 2 vols (Paris: Sirey, 1965), I, 729-41

Verdier, René, 'Guillaume de Plaisians, une succession médiévale (1314)', Revue d'histoire et du patrimoine en Dauphiné, 11 (2000), 99-110

_- 'Guillaume de Plaisians, itinéraire d'un légiste', in Vienne au crépuscule des templiers, ed. by Roger Lauxerois (Grenoble: Presses universitaries de Grenoble, 2014), pp. 83-92

Vic, Claude de, and Jean-Joseph Vaissete, Histoire générale de Languedoc, avec des notes et les pièces justificatives, ed. by Édouard Dulaurier and others, 15 vols (Toulouse: Édouard Privat, 1872-93)

Vidal, Jean-Marie, 'Bernard Saisset', Revue des Sciences religieuses, 5 (1925), 417-38, 565-90; 6 (1926), 50-77, 177-98, 371-93

—, Documents sur les origines de la province ecclésiastique de Toulouse, 1295-1318 (Roma: P. Cuggiani, 1901)

- Le tribunal d'inquisition de Pamiers (Toulouse: Privat, 1906)

Vincent, The Holy Blood: King Henry III and the Westminster Blood Relic (Cambridge: Cambridge University Press, 2001)

Walther, Helmut G., 'Innocenz III. und die Bekämpfung der Ketzer im Kirchenstaat: ein Beitrag zur Wirkungsgeschichte von Vergentis in senium', in Religiöse Bewegungen im Mittelalter: Festschrift für Matthias Werner, ed. by Enno Bünz, Stefan Tebruck, and Helmut G. Walther (Köln: Bölhau, 2007), pp. 723-35 